\title{
Maintenance Action Work Plan for Waste Area Grouping 1 Inactive Tanks 3001-B, 3004-B, T-30, and 3013 at Oak Ridge National Laboratory, Oak Ridge, Tennessee
}

\author{
DISCLAIMER
}

\begin{abstract}
This report was prepared as an account of work sponsored by an agency of the United States Government. Neither the United States Government nor any agency thereof, nor any of their employees, makes any warranty, express or implied, or assumes any legal liability or responsibility for the accuracy, completeness, or usefulness of any information, apparatus, product, or process disclosed, or represents that its use would not infringe privately owned rights. Reference herein to any specific commercial product, process, or service by trade name, trademark, manufacturer, or otherwise does not necessarily constitute or imply its endorsement, recommendation, or favoring by the United States Government or any agency thereof. The views and opinions of authors expressed herein do not necessarily state or reflect those of the United States Government or any agency thereof.
\end{abstract}

Date Issued—July 1995

Prepared by

CDM Federal Programs Corporation

Oak Ridge, Tennessee 37830

under contract DE-AC05-99052C

Document Control No. 7913-330-DR-BBVD

Prepared for

U.S. Department of Energy

Office of Environmental Restoration and Waste Management

under budget and reporting code EW 20

OAK RIDGE NATIONAL LABORATORY

Oak Ridge, Tennessee 37831-7101

managed by

LOCKHEED MARTIN ENERGY SYSTEMS, INC.

for the

U.S. DEPARTMENT OF ENERGY

under contract DE-AC05-84OR21400 


\section{DISCLAIMER}

Portions of this document may be illegible in electronic image products. Images are produced from the best available original document. 
MAINTENANCE ACTION WORK PLAN

FOR WASTE AREA GROUPING 1 INACTIVE TANKS 3001-B, 3004-B, T-30, AND 3013

AT OAK RIDGE NATIONAL LABORATORY, OAK RIDGE, TENNESSEE
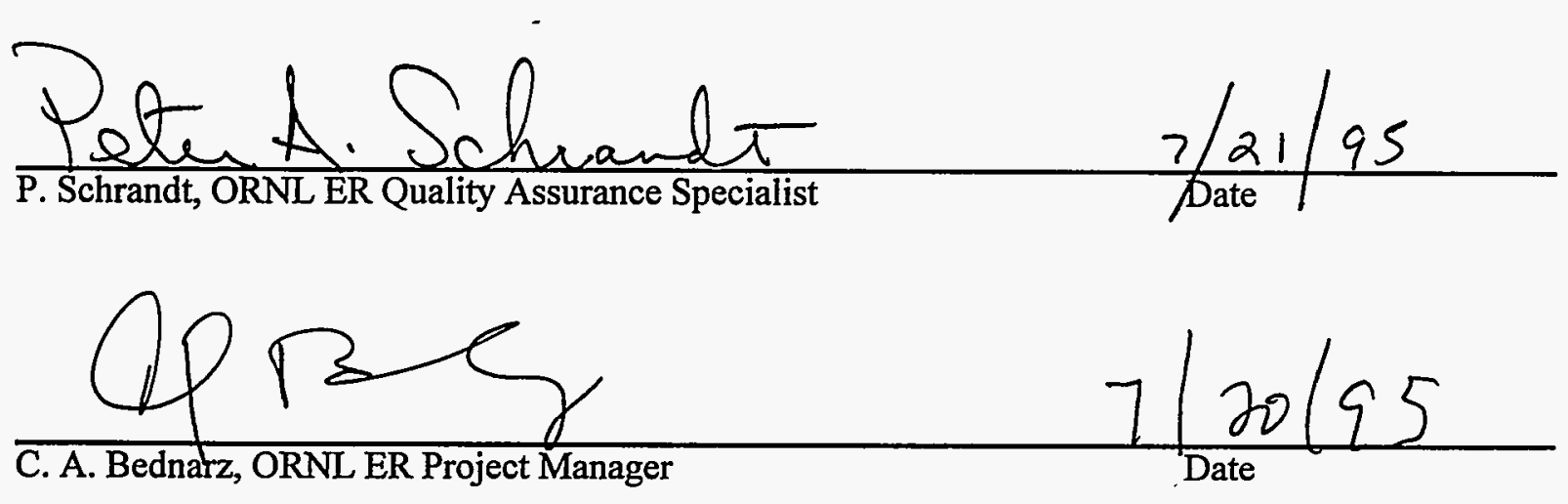

C. A. Bednarz, ORNL ER Project Manager

Date

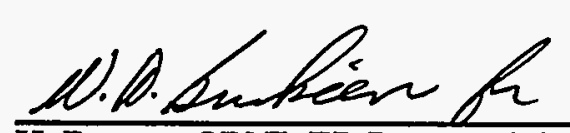

H. Boston, ORNL ER Program Manager

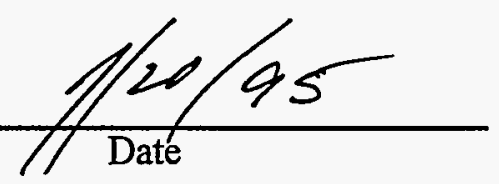




\section{PREFACE}

This Maintenance Action Work Plan describes the procedures required to safely remediate four inactive tanks at Waste Area Grouping 1 at the Oak Ridge National Laboratory, Oak Ridge, Tennessee. The work described in this document is being conducted as a voluntary maintenance action by the U.S. Department of Energy. This document describes the maintenance action approach, health and safety, waste management, and quality assurance. 


\section{CONTENTS}

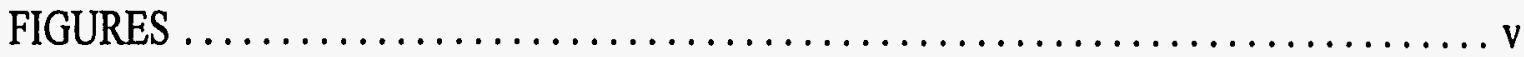

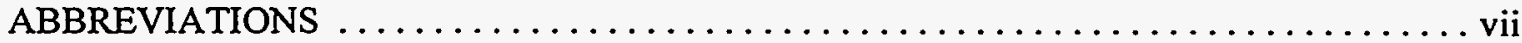

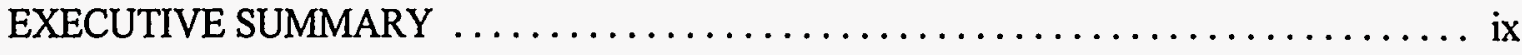

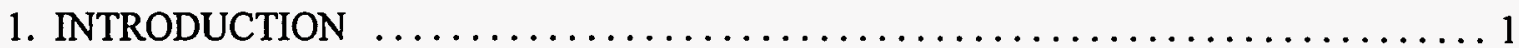

1.1 MAINTENANCE ACTION OVERVIEW $\ldots \ldots \ldots \ldots \ldots \ldots \ldots \ldots \ldots \ldots, \ldots \ldots \ldots$

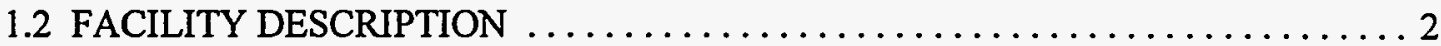

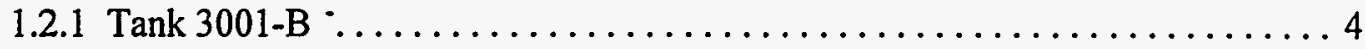

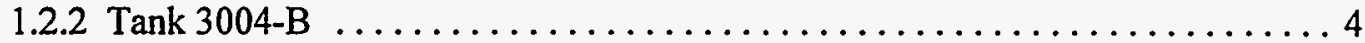

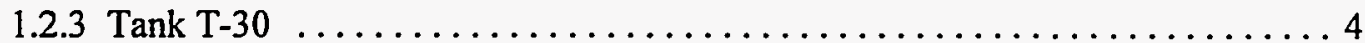

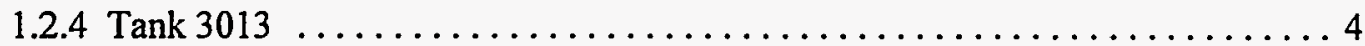

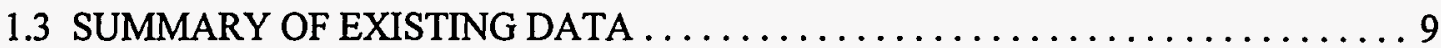

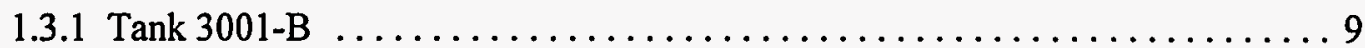

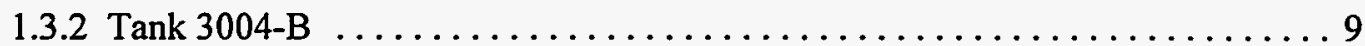

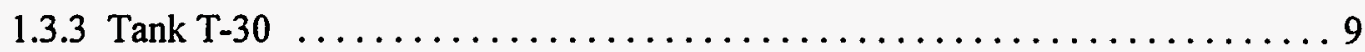

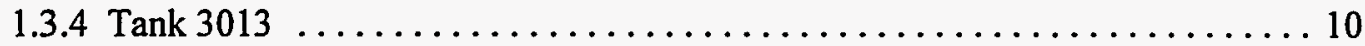

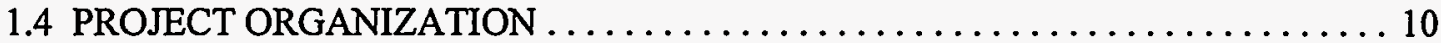

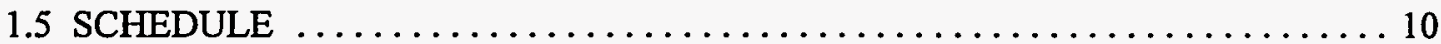

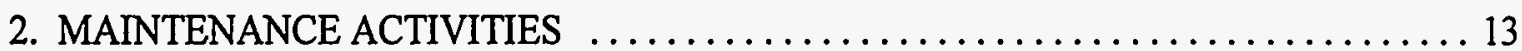

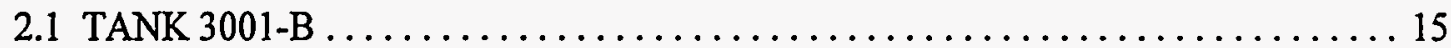

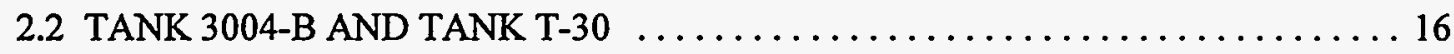

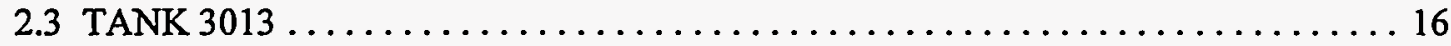

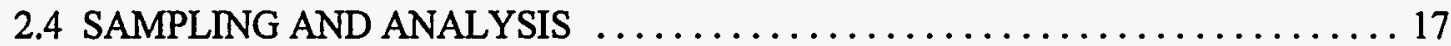

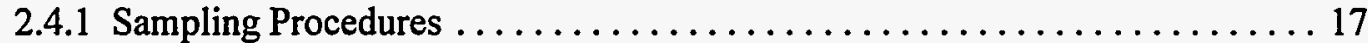

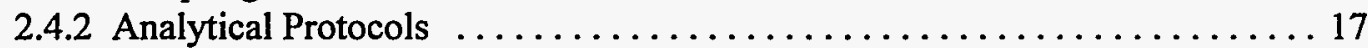

2.4.3 Quality Assurance/Quality Control Samples $\ldots \ldots \ldots \ldots \ldots \ldots \ldots \ldots \ldots$

2.4 .4 Sample Handling $\ldots \ldots \ldots \ldots \ldots \ldots \ldots \ldots \ldots \ldots \ldots \ldots \ldots \ldots \ldots \ldots \ldots, 18$

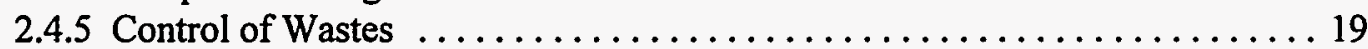

2.4.6 Data Management .................................. 19

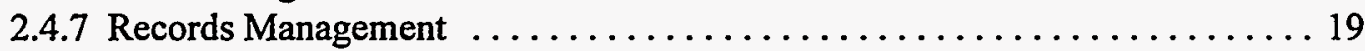

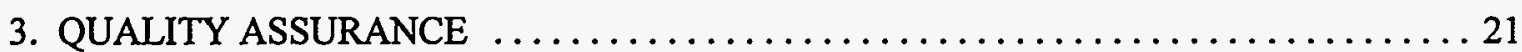

3.1 ORGANIZATIONAL AND FUNCTIONAL RESPONSIBILITIES $\ldots \ldots \ldots \ldots \ldots 21$

3.1.1 Project Personnel ................................... 21

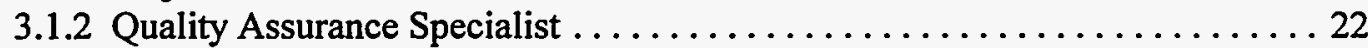

3.2 TRAINING REQUIREMENTS $\ldots \ldots \ldots \ldots \ldots \ldots \ldots \ldots \ldots \ldots \ldots \ldots \ldots \ldots \ldots \ldots \ldots \ldots \ldots, 22$

3.3 FIELD QUALITY ASSURANCE/QUALITY CONTROL $\ldots \ldots \ldots \ldots \ldots \ldots .23$

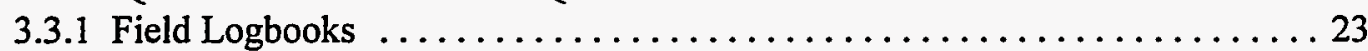

3.3.2 Decontaminating Equipment $\ldots \ldots \ldots \ldots \ldots \ldots \ldots \ldots \ldots \ldots \ldots \ldots \ldots \ldots \ldots \ldots \ldots \ldots, 23$

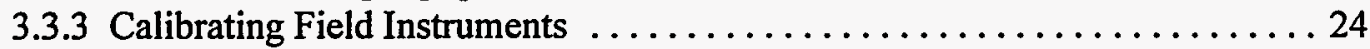

3.4 RECORDS MANAGEMENT ............................... 24

3.5 PROGRAMMATIC QUALITY ASSURANCE/QUALITY CONTROL $\ldots \ldots \ldots .24$

3.5.1 Readiness Assessment . . . . . . . . . . . . . . . . . . . . . . . . . 25 
3.5.2 Responsibilities of Field Personnel . . . . . . . . . . . . . . 25

3.5.3 Responsibilities of Quality Assurance Personnel . . . . . . . . . . 25

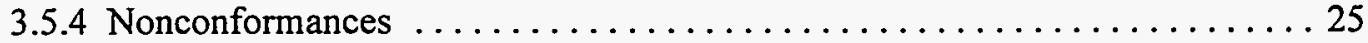

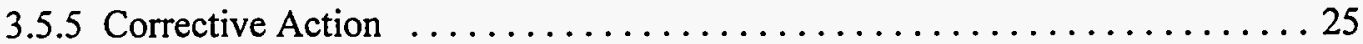

4. BEST MANAGEMENT PRACTICES . . . . . . . . . . . . . . . . . 27

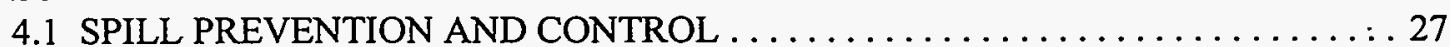

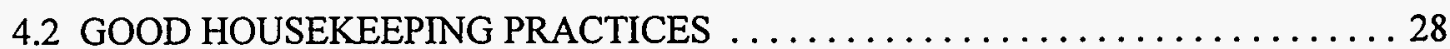

4.3 INSPECTIONS FOR ENVIRONMENTAL COMPLIANCE $\ldots \ldots \ldots \ldots \ldots \ldots \ldots$

4.4 SEDIMENT AND EROSION CONTROL MEASURES . . . . . . . . . . . . . 29

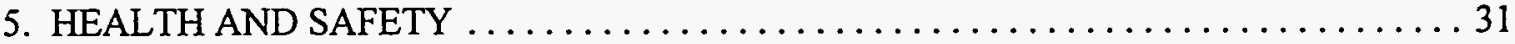

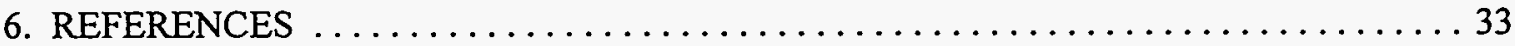

APPENDIX A: WELDING SPECIFICATIONS $\ldots \ldots \ldots \ldots \ldots \ldots \ldots \ldots \ldots \ldots \ldots \ldots \ldots$ 


\section{FIGURES}

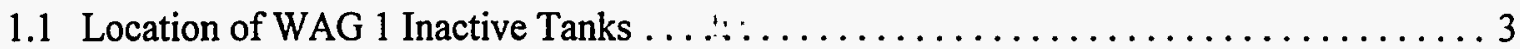

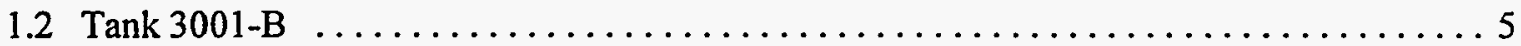

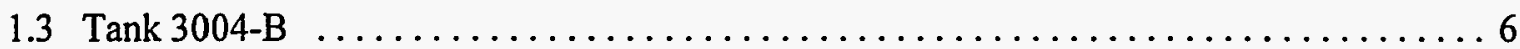

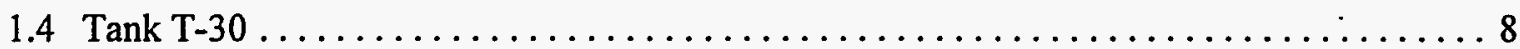

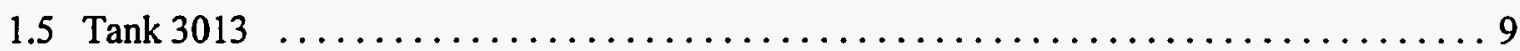

1.6 WAG 1 Inactive Tanks Maintenance Action project organization chart $\ldots \ldots \ldots \ldots \ldots 11$

1.7 WAG 1 Inactive Tanks Maintenance Action project schedule . . . . . . . . . . . 12 


\section{ABBREVIATIONS}

$\begin{array}{ll}\text { AST } & \text { Advanced Systems Technology, Inc. } \\ \text { DMC } & \text { Data Management Center } \\ \text { DOE } & \text { U.S. Department of Energy } \\ \text { Energy Systems } & \text { Martin Marietta Energy Systems, Inc. } \\ \text { EPA } & \text { U.S. Environmental Protection Agency } \\ \text { ER } & \text { Environmental Restoration } \\ \text { ESP } & \text { Environmental Surveillance Procedure } \\ \text { HASL } & \text { Health and Safety Laboratory } \\ \text { HAZWOPER } & \text { Hazardous Waste Operations and Emergency Response } \\ \text { LLLW } & \text { liquid low-level waste } \\ \text { LMES } & \text { Lockheed Martin Energy Systems, Inc. } \\ \text { MDA } & \text { minimum detectable activity } \\ \text { OREIS } & \text { Oak Ridge Environmental Information System } \\ \text { ORNL } & \text { Oak Ridge National Laboratory } \\ \text { ORR } & \text { Oak Ridge Reservation } \\ \text { OSHA } & \text { Occupational Safety and Health Administration } \\ \text { QA } & \text { quality assurance } \\ \text { QC } & \text { quality control } \\ \text { RCRA } & \text { Resource Conservation and Recovery Act } \\ \text { WAG } & \text { Waste Area Grouping }\end{array}$




\section{EXECUTIVE SUMMARY}

This Maintenance Action Work Plan has been prepared to document the activities and procedures for the remediation of four inactive, low-level radioactive tanks at Waste Area Grouping 1, from the Category D list of tanks in the Federal Facility Agreement for the Oak Ridge Reservation (EPA et al. 1994). The four tanks to be remediated are tanks 3001-B, 3004-B, T-30, and 3013. Three of the tanks (3001-B, 3004-B, and T-30) will be physically removed from the ground. Because of logistical issues associated with excavation and site access, the fourth tank (3013) will be grouted in place and permanently closed.

Removal of tanks 3001-B, 3004-B, and T-30 involves removing the vault lids, cutting the tanks loose from associated piping and mounts, and removing the tanks from the vaults. After removal, the piping will be sealed or reconnected with additional piping. The vaults then will be grouted full and the vault lids will be replaced. The Tank T-30 vault cover will be disposed as scrap metal. The Tank T-30 vault will have a new concrete cap installed over the grout-filled vault. After removal, the three tanks will be placed in Sealand ${ }^{\text {TM }}$ containers and transported to an off-site disposal facility.

Because Tank 3013 originally was direct-buried in the ground, it will be closed in place. The ground surface above the tank will be excavated to a depth of approximately $4 \mathrm{ft}$ to expose associated piping. Grout will be pumped into the tank through the vent pipe, and all piping will be cut below grade level and sealed after grouting is completed. The excavated pit then will be backfilled. Any fluids generated from the cut pipes will be analyzed for radiological parameters to ensure that waste disposal criteria are met.

Other plans have been prepared in support of this action, including a Site-Specific Health and Safety Plan, a Waste Management Plan, a Hoisting and Lifting Plan, and a Readiness Assessment Plan. This work is scheduled to begin in July 1995, and to be completed by September 1995. 


\section{INTRODUCTION}

\subsection{MAINTENANCE ACTION OVERVIEW}

This work plan describes the approach and procedures required to safely remediate four inactive tanks, backfill the emptied vaults or holes, repair the ground surface as appropriate, and dispose of the removed tanks. The tanks were formerly used as liquid low-level waste (LLLW) storage at Waste Area Grouping (WAG) 1 at Oak Ridge National Laboratory (ORNL) at Oak Ridge, Tennessee. These activities are being performed as a voluntary maintenance action by the U.S. Department of Energy (DOE). The work is being implemented by Lockheed Martin Energy Systems, Inc. (LMES), as a routine maintenance activity.

The tanks to be remediated are designated as "Batch I (Series 1)" tanks, and are among 55 inactive LLLW tanks currently identified at ORNL. The four tanks are Tank 3001-B, Tank 3004-B, Tank T-30, and Tank 3013. Three tanks-3001-B, 3004-B, and T-30-will be physically removed and disposed of. The fourth tank, 3013, will be filled with grout and closed in place.

The maintenance action on the four tanks consists of the following tasks:

- relocating the staircase leading from the second story of Building 3001 to the concrete pad above Tank 3001-B;

- excavating soil and asphalt above Tank 3001-B;

- $\quad$ excavating soil from around Tank 3013;

- removing vault covers from tanks 3001-B, 3004-B, and T-30;

- sampling pipelines in all four tanks;

- cutting pipelines in all four tanks and any anchoring devices on tanks 3001-B, 3004-B, and $\mathrm{T}-30$, and capping pipelines in tanks 3004-B, T-30, and 3013;

- $\quad$ removing tank flange and aboveground piping sections from Tank 3013;

- welding new lifting lugs on tanks 3001-B, 3004-B, and T-30;

- removing, capping, wrapping, and moving tanks 3001-B, 3004-B, and T-30 to staged Sealand ${ }^{\mathrm{TM}}$ containers for transport to Science Ecology Group, Inc., for recycling, and conducting any decontamination and sampling necessary to meet waste acceptance criteria;

- welding new pipe to an existing pipeline to form a continuous pipe run through the Tank 3001-B vault;

- welding endcaps on cut pipes left in place; 
- $\quad$ filling vaults and Tank 3013 with grout;

- pouring concrete pad to replace asphalt in the vicinity of Tank $3001-\mathrm{B}$ and installing a reinforced concrete pad over the grout-filled Tank T-30 vault;

- backfilling the Tank 3013 excavation; and

- $\quad$ restore ground surface as appropriate.

This work plan is organized in the following manner.

- Section 1-introduction, description and history, schedule;

- Section 2-maintenance activities;

- Section 3-quality assurance;

- $\quad$ Section 4-best management practices;

- Section 5-health and safety; and

- Section 6-references.

\subsection{FACILITY DESCRIPTION}

ORNL is in the East Tennessee valley and ridge topographic region. It occupies the south-central portion of the Oak Ridge Reservation (ORR), approximately $16 \mathrm{~km}$ (10 mi) southwest of Oak Ridge and $24 \mathrm{~km}$ (15 mi) west of Knoxville, Tennessee (Fig. 1.1).

The ORNL complex was created during World War II to facilitate production of atomic weapons. After completion of the wartime efforts, the ORNL mission was changed to consist of radiological research and the development and production of isotopes. Later, the mission was broadened to include research beyond strictly radiological topics.

Installation began on the LLLW process system as ORNL was being constructed in the 1940s. No master plan was developed for connecting to the LLLW lines. The system was designated to collect, neutralize, transfer, and concentrate aqueous radioactive waste solutions from generator facilities throughout ORNL. These facilities included research and development laboratories, nuclear reactors, and radioisotope production facilities. To control input into the LLLW system, tanks were used either to accumulate the contaminated liquid in source buildings or to receive liquid from sinks and drains. The contaminated liquid then was released to the LLLW system.

Over the years, tanks in the LLLW system were deactivated as their integrity was breached or as processes at ORNL were discontinued. In addition, the LLLW lines to the tanks that were no longer in use were inactivated. The inactive tanks and lines then were placed under a surveillance and maintenance program.

WAG 1 includes most of the main plant area of ORNL, a restricted access area enclosed by a security fence. Three of the WAG 1 inactive tanks to be remediated during this maintenance action are inside the security fence of the main facility. The fourth tank is located in a vault outside the north security fence, near the public access walkway. All of the tanks are within the ORNL historical preservation area. However, because the tanks are below-ground structures, they are not eligible for listing as cultural resources. The action taken to remediate the tanks will involve 


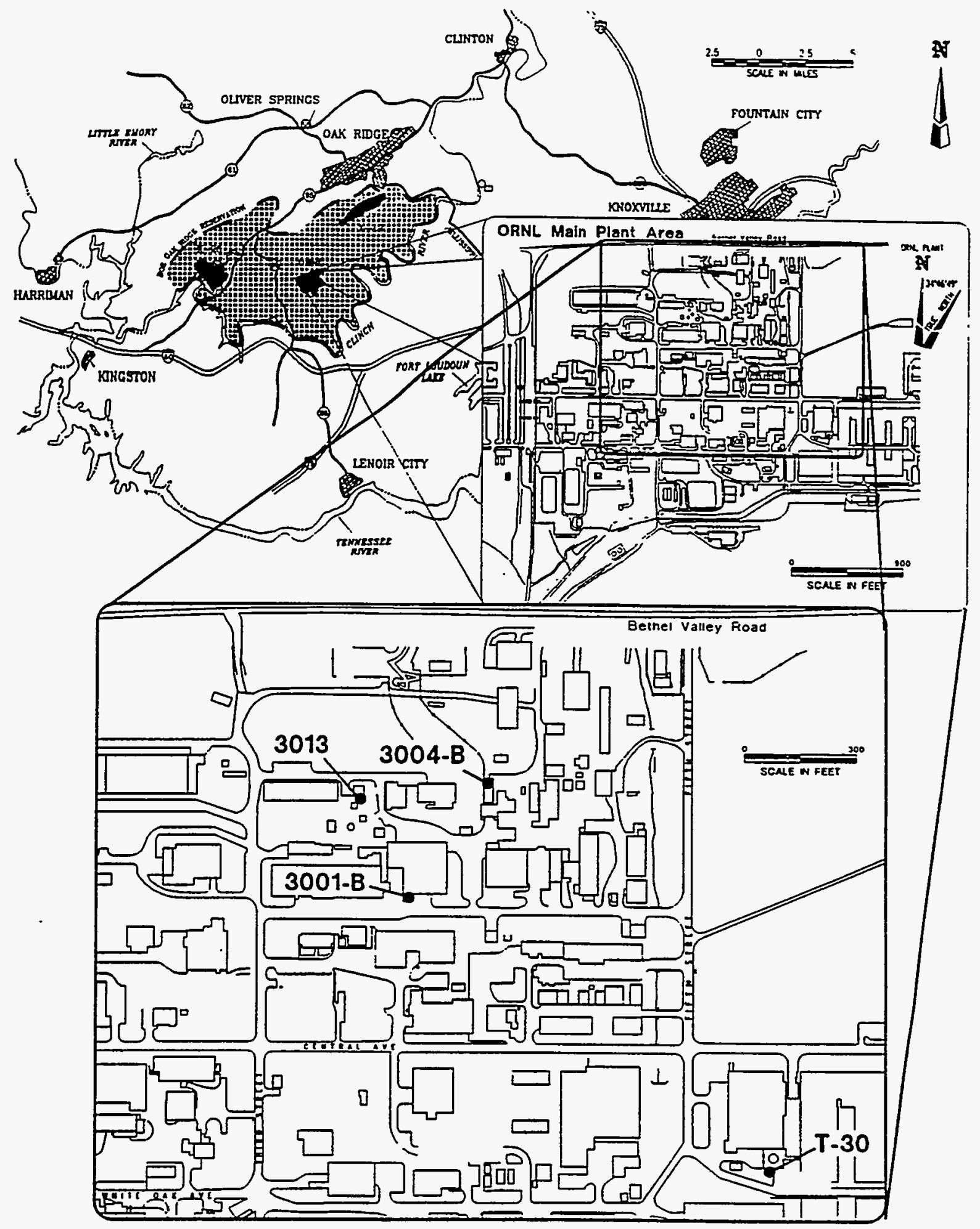


historical preservation if the actions affect the appearance and/or aesthetics of the historical district in which they are located.

\subsubsection{Tank 3001-B}

Tank 3001-B, an approximately 1,135-L (300-gal) stainless steel tank, is located in a vault under the outside stairway landing adjacent to the south wall of Building 3001 . System piping consists of one 3-in. stainless-steel, discharge line with an isolation valve that connects to a 2-in., stainless steel, header running from Building 3019 to Tank WC-19 (Fig. 1.2). The hot laboratory equipment was removed around 1965, and the area now houses a water demineralizer. Tank 3001-B is connected in line with the demineralizer. The two drains to Tank 3001-B have been sealed.

\subsubsection{Tank 3004-B}

Tank 3004-B, an approximately 378-L (100-gal), stainless steel tank, is located in a vault just east of Building 3008. System piping consists of a 2-in., stainless steel, inlet leader that served drains in Building 3005, and a 2-in., stainless steel, discharge line to a valve box near Building 3001, where it joins a header connecting to active Tank WC-19 (Fig. 1.3). Tank 3004-B was installed in 1956 to serve the Low Intensity Test Reactor in Building 3005, and was removed from service in the late 1960s. Building 3005 now serves as a machine shop. All drains to Tank 3004-B have been sealed.

\subsubsection{Tank T-30}

Tank T-30, a 3122-L (825-gal), stainless steel tank, is located in a vault south of Building 4507. The tank was installed in 1961 in an in-ground vault, and was removed from service around 1980. The tank stored radioactive materials for the Curium Recovery Facility in Building 4507. System piping consists of a 1-in., stainless steel, drain line from Building 4507; a 2-in., stainless steel, overflow line; and a 0.5-in., stainless steel, steam-jet-discharge line (Fig. 1.4). A hole was cut into the tank for sampling in 1989, and a rubber stopper was put in this hole. The tank is on vessel offgas. The pit is kept at negative pressure by the cell ventilation system; the pressure is read in Building 4507.

\subsubsection{Tank 3013}

Tank 3013, an approximately 1515-L (400-gal), stainless steel tank, was buried in 1949 approximately $3.6 \mathrm{~m}$ ( $4 \mathrm{yd}$ ) below the surface, just south of Building 3013, to service Building 3013 in which an environmental processing laboratory dealt with low-level contaminated environmental samples. No vault is associated with this tank. System piping consists of a 2-in., stainless steel, inlet line from the cell beneath the floor of Building 3013; a 2-in., stainless steel vent to the off-gas system; and a 2-in., stainless steel, discharge line that is cut and capped approximately $15 \mathrm{~m} \mathrm{(50 \textrm {ft } )}$ south of the tank (Fig. 1.5). In addition, two 0.25-in. instrumentation lines run from the tank to Building 3013 and are terminated with caps just above the floor of the building. The discharge steam jet is above ground, and its steam supply has been removed. Liquid was removed from the tank in September 1993. 


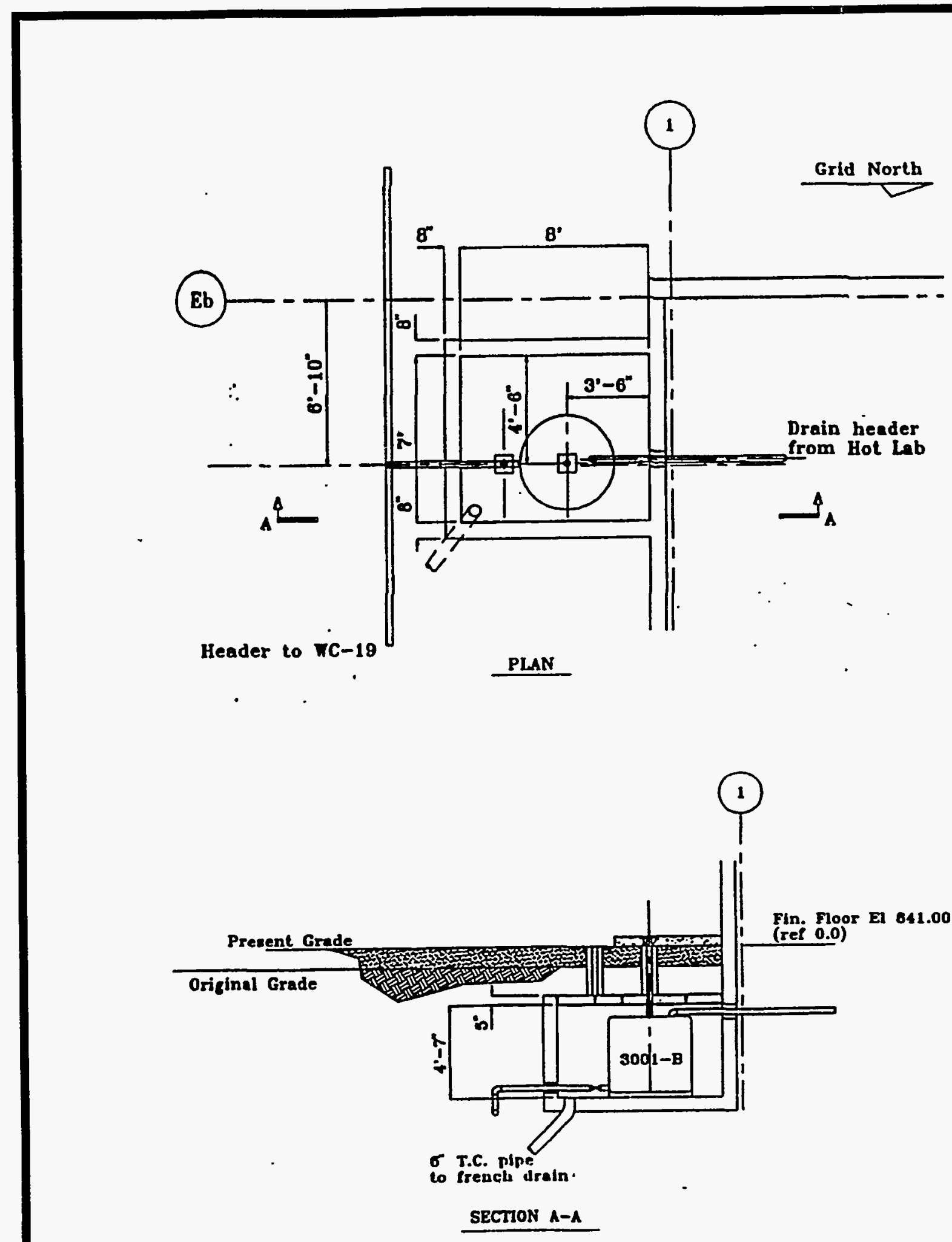

MiN

TANK 3001-B 

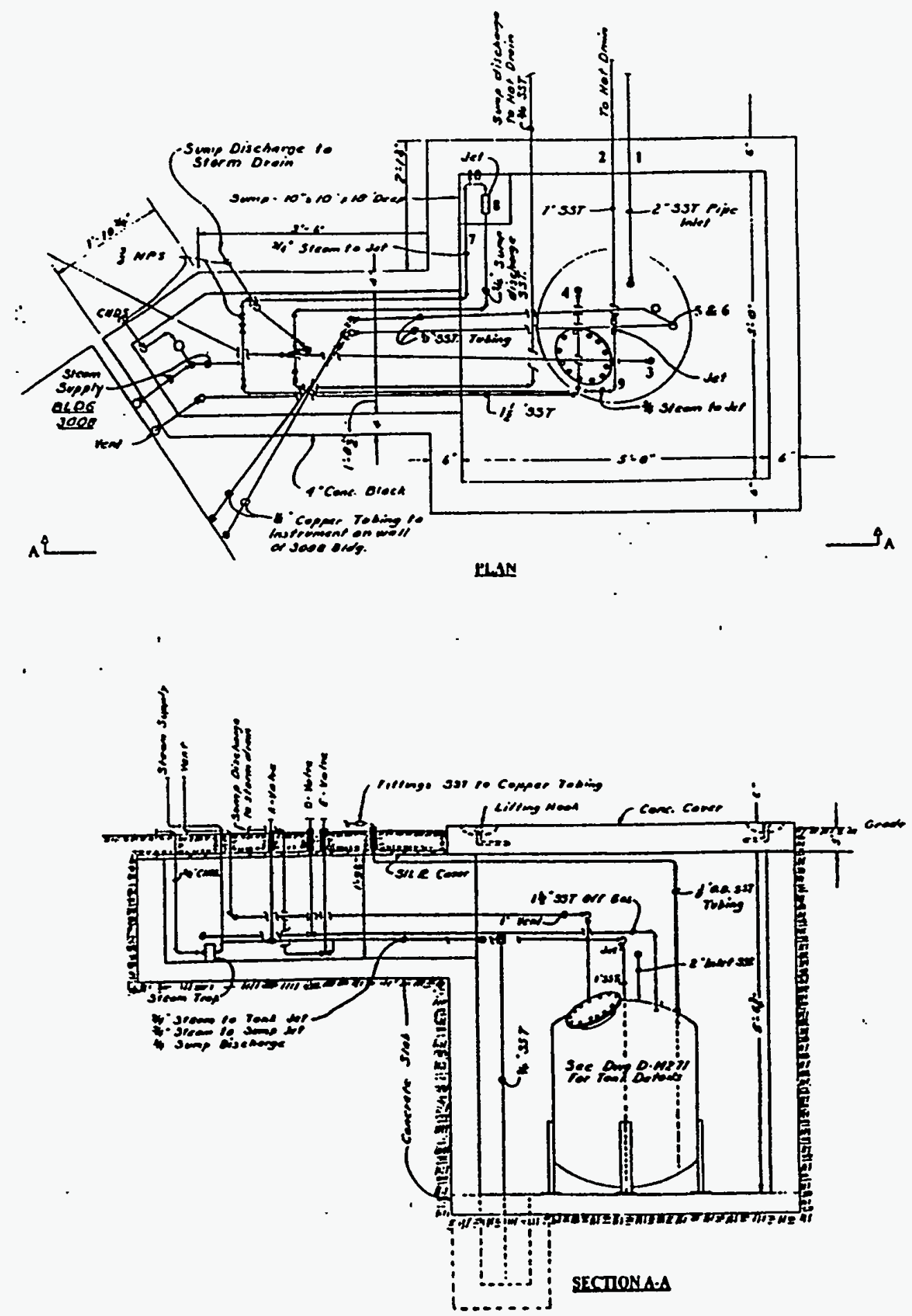

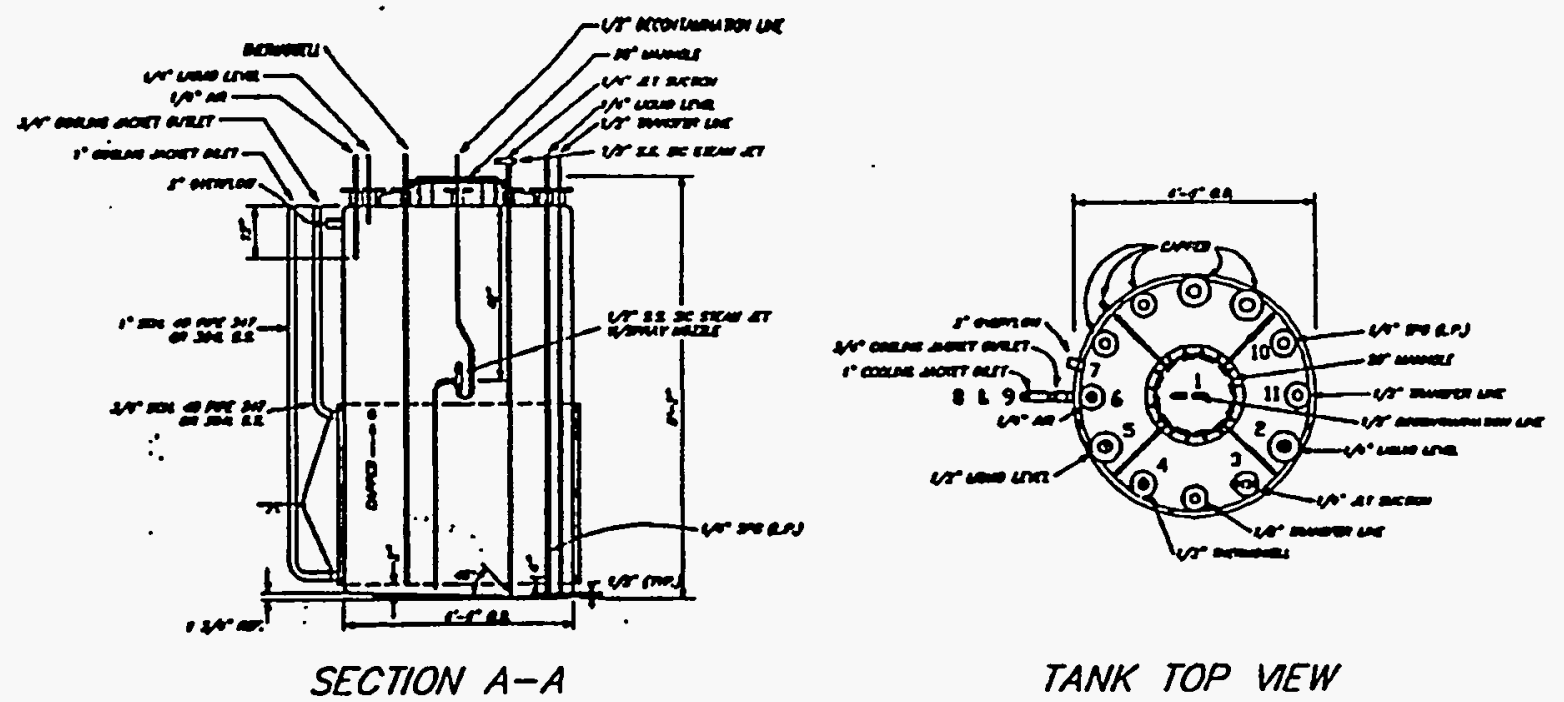

TANK TOP VEW

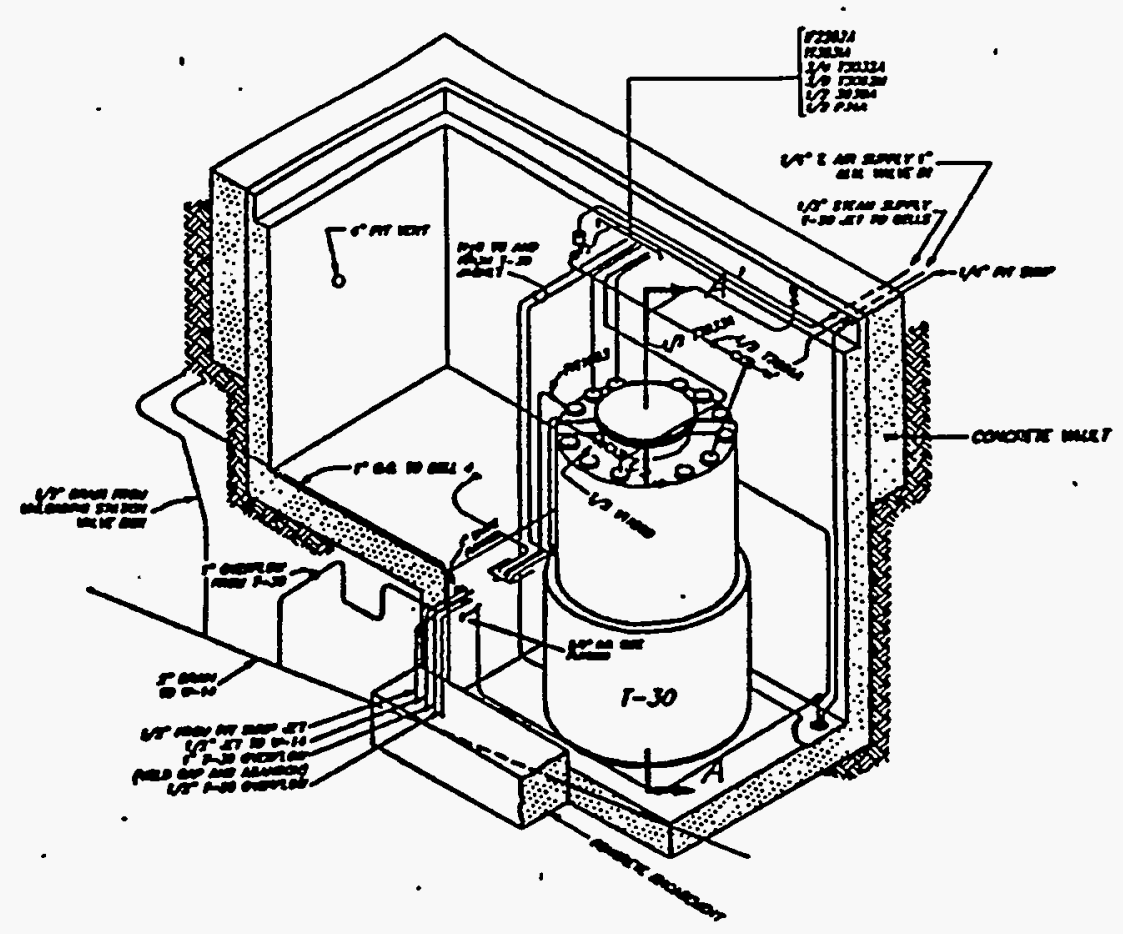

ISOME:IRIC VI. W 

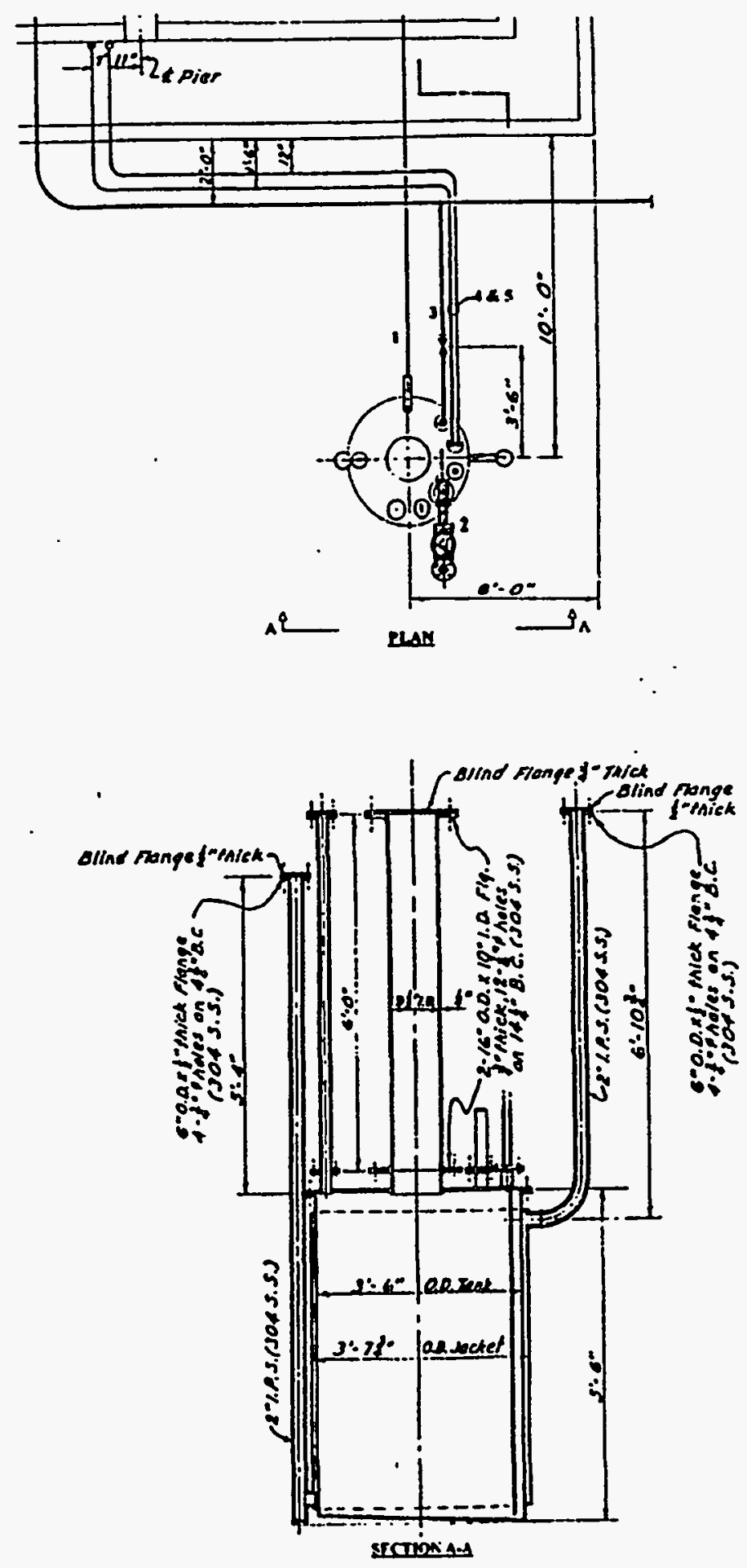


\subsection{SUMMARY OF EXISTING DATA}

\subsubsection{Tank 3001-B}

Sampling of Tank 3001-B was performed on July 17, 1992. At that time, $1.9 \mathrm{~cm}(0.75 \mathrm{in}$.) of liquid remaining in the tank was sampled; no sludge was present. Resource Conservation and Recovery Act (RCRA) metals were detected at concentrations ranging between 0.002 to $0.216 \mathrm{mg} / \mathrm{L}$. The results of the physical measurement of the liquid sample were unremarkable and within the range of acceptability. No volatile organic compounds were detected. The gamma scan indicated that $289 \mathrm{~Bq} / \mathrm{mL}$ of ${ }^{137} \mathrm{Cs}, 83.3 \mathrm{~Bq} / \mathrm{mL}$ of ${ }^{90} \mathrm{Sr}, 1.47 \mathrm{Bp} / \mathrm{mL}$ of ${ }^{60} \mathrm{Co}$, and $0.49 \mathrm{~Bq} / \mathrm{mL}$ of ${ }^{3} \mathrm{H}$ were present. The gross fissile measurements, performed to address criticality and accountability issues, were $0.279 \mathrm{~Bq} / \mathrm{mL}$ of ${ }^{239} \mathrm{Pu}$ equivalency and $0.19 \mathrm{Bp} / \mathrm{mL}$ of ${ }^{235} \mathrm{U}$ equivalency.

The tank was inspected by video camera in January 1995, and was found to be empty by definition: the remaining $2 \mathrm{~cm}(0.75 \mathrm{in}$.) of liquid cannot be removed by pumping. This tank is categorized as an industrial facility in accordance with the requirements of "Hazard Baseline Documentation" (DOE-EM-STD-5502-94).

\subsubsection{Tank 3004-B}

-Sampling of Tank 3004-B was performed on May 27, 1992. At this time, the monitored radiation level at the tank access was $0.8 \mathrm{mR} /$ hour. Liquid was present in the tank to the top of the tank flange. Samples of the liquid were taken and analyzed. RCRA metals were detected, including $\mathrm{Ba}, \mathrm{Hg}, \mathrm{Ag}, \mathrm{Ar}$, and $\mathrm{Cr}$. The maximum metals concentration was $0.0237 \mathrm{mg} / \mathrm{L}$. No volatile organic compounds were detected. The gamma scan indicated the presence of ${ }^{137} \mathrm{Cs}$ at a maximum level of $0.558 \mathrm{~Bq} / \mathrm{mL}$. No sludge was present in the tank. The tank was emptied in September 1993.

The tank was inspected in February 1995. It was filled to the top of the tank flange. Approximately $38 \mathrm{~cm}$ (15 in.) of water was in the vault. No sludge was observed in the tank. Field monitoring of the tank near the flange and of the water in the vault detected no radiological contamination. The water in the vault was sampled in 1995 as well. This tank is categorized as an industrial facility in accordance with the requirements of "Hazard Baseline Documentation" (DOE-EM-STD-5502-94).

\subsubsection{Tank T-30}

Sampling of Tank T-30 was performed most recently in 1989. Liquid was found in the tank to the top of the flange. Samples of the liquid were taken and analyzed. RCRA metals were detected, but at levels well below concentration of concern. Volatile organic compounds were detected, including $9 \mu \mathrm{g} / \mathrm{L}$ of acetone and $10 \mu \mathrm{g} / \mathrm{L}$ of toluene. DAI-gas chromatography determined that $11 \mathrm{mg} / \mathrm{L}$ of methanol also was present. A gamma scan indicated that $4 \mathrm{~Bq} / \mathrm{mL}$ of ${ }^{137} \mathrm{Cs}$, $1.6 \mathrm{~Bq} / \mathrm{mL}$ of ${ }^{3} \mathrm{H}$, and $15 \mathrm{~Bq} / \mathrm{mL}$ of ${ }^{90} \mathrm{Sr}$ were present. No sludge was reported in the tank.

The tank was to be inspected by video camera in March 1995. However, because the vault and exterior of the tank bore removable alpha contamination, no additional sampling was attempted. Decontamination and removal of RCRA-regulated and radiological material is currently under way. Those actions are outside the scope of this plan. 


\subsubsection{Tank 3013}

Sampling of Tank 3013 was performed on May 19, 1992. At that time, approximately $2.2 \mathrm{~m}$ ( $7 \mathrm{ft}$ ) of liquid was sampled; no sludge was present. RCRA metals were detected, including Ar, $\mathrm{Ba}$, $\mathrm{Cr}, \mathrm{Hg}$, and $\mathrm{Pb}$. The highest metals concentration was $5.89 \mathrm{mg} / \mathrm{L}$. The results of the physical measurement of the liquid sample were unremarkable and within the range of acceptability. No volatile organic compounds were detected. Results of the radiochemical screening and gamma spectroscopy of the near-neutral liquid showed levels less than the minimum detectable activities (MDAs) of the analytical systems.

The tank was inspected by video camera in February 1995 and found to be approximately half-filled with liquid. The gasket at the opening into the tank was damaged, and appeared to provide a pathway for rain and/or surface water to enter the tank. The tank was sampled in 1995 as well. This tank is categorized as an industrial facility in accordance with the requirements of "Hazard Baseline Documentation" (DOE-EM-STD-5502-94).

\subsection{PROJECT ORGANIZATION}

Figure 1.6 displays the organization for this project. ORNL LMES Environmental Restoration (ER) is providing program and project management. LMES Engineering personnel are providing engineering project management, and will oversee the field activities. Advanced Systems Technology, Inc. (AST), will be conducting the actual field implementation activities, including all hoisting and lifting tasks. AST will provide a Field Manager/Site Safety and Health Officer for the project. Other organizations and personnel providing specific project support are identified in Fig. 1.6.

\subsection{SCHEDULE}

Figure 1.7 displays the overall project schedule. The field activities are expected to commence in July 1995 and to finish in September 1995. All documentation is expected to be finished and approved by June 30,1995. A readiness assessment will be conducted in early July, and the field activities will start immediately after the readiness assessment is completed. The fieldwork will be completed approximately on September 1, and a closure letter will be submitted to DOE at the end of September 1995. 


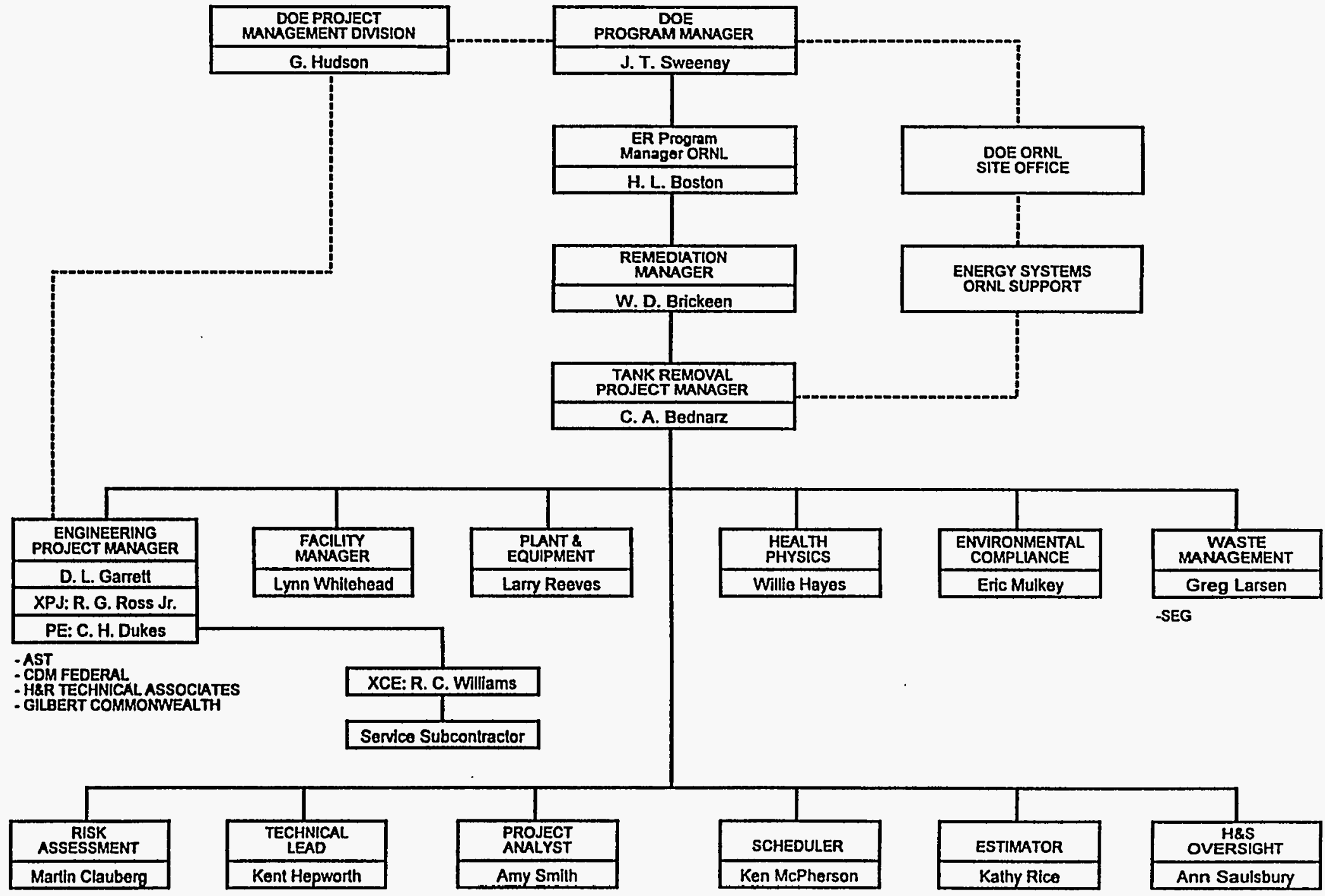

s234HER

WAG 1 INACTIVE TANK MAINTENANCE ACTION PROJECT ORGANIZATION CHART

OAK RIDGE NATIONAL LABORATORY OAK RIDGE, TENNESSEE 


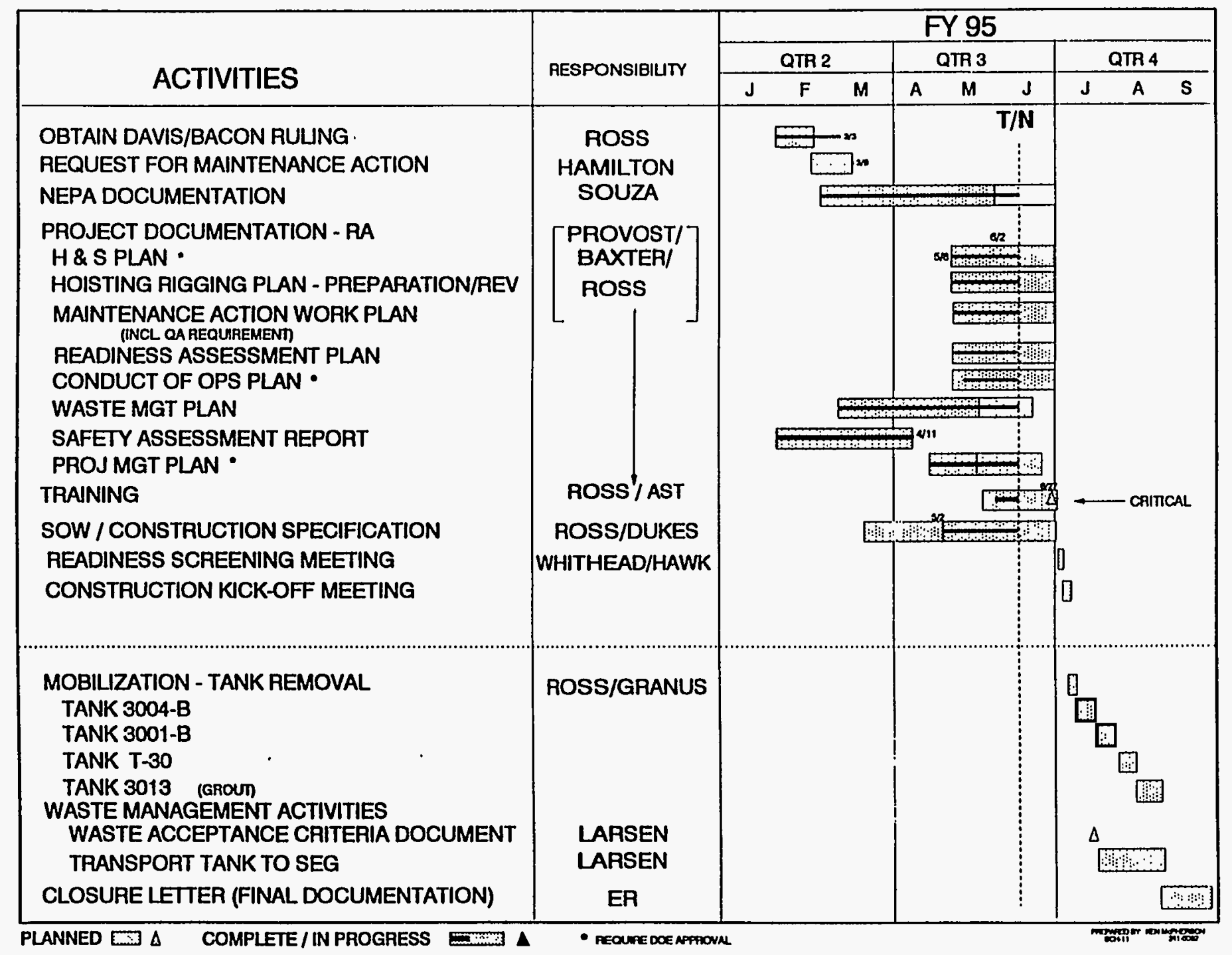

\section{WAG 1 INACTIVE TANK MAINTENANCE ACTION \\ PROJECT SCHEDULE \\ OAK RIDGE NATIONAL LABORATORY OAK RIDGE, TENNESSEE}




\section{MAINTENANCE ACTIVITIES}

The maintenance action on the four tanks consists of the following tasks:

- relocating the staircase leading from the second story of Building 3001 to the concrete pad above Tank 3001-B;

- excavating soil and asphalt above Tank 3001-B;

- excavating soil from around Tank 3013;

- removing vault covers from tanks $3001-\mathrm{B}, 3004-\mathrm{B}$, and $\mathrm{T}-30$;

- sampling pipelines in all four tanks;

- cutting pipelines in all four tanks and any anchoring devices on tanks 3001-B, 3004-B, and $\mathrm{T}-30$, and capping pipelines in tanks 3004-B, T-30, and 3013;

- removing tank flange and aboveground piping sections from Tank 3013;

- welding new lifting lugs on tanks 3001-B, 3004-B, and T-30;

- removing, capping, wrapping, and moving tanks 3001-B, 3004-B, and T-30 to staged Sealand ${ }^{\text {Th }}$ containers for transport to Science Ecology Group, Inc., for recycling, and conducting any decontamination and sampling necessary to meet waste acceptance criteria;

- welding new pipe to an existing pipeline to form a continuous pipe run through the Tank 3001-B vault;

- welding endcaps on cut pipes left in place;

- filling vaults and Tank 3013 with grout;

- pouring a concrete pad to replace asphalt in the vicinity of Tank 3001-B and installing a reinforced concrete pad over the grout-filled Tank T-30 vault;

- backfilling the Tank 3013 excavation; and

- restoring the ground surface, as appropriate.

The radiological conditions of the outer tank surfaces and the vault interiors are not known. Therefore, all work inside and around the tanks will be assumed to be in a contamination area until determined otherwise. Hazardous Waste Operations and Emergency Response (HAZWOPER) boundaries will be set up at each site, and appropriate personal protective equipment will be specified. All vaults are considered to be confined spaces, and Confined Space Entry Permits will be obtained.

The "Service Contract Specification for Inactive Tanks 3001-B, 3004-B, 3013, and T-30" (ESO:PX4836-01) provides general and specific information describing how the activities will be 
performed. All work conducted under this task will adhere to the requirements of the Service Contract Specification.

Once the tanks are accessible, the exact piping and anchoring configuration will be determined, and the plan for cutting will be finalized. A Sawzall ${ }^{\mathrm{TM}}$ or torch will be used to cut through the connecting piping and attached anchoring devices. A Hot Work/Burning permit will be obtained if hot cutting is to occur. In addition to cutting the piping, any anchoring devices will be identified and disconnected. Use of a Sawzall ${ }^{\mathrm{TM}}$ also is the preferred method in this case, but, depending on the exact type of anchoring and its configuration, hot cutting may be necessary.

Pipelines in all four tanks will be sampled to determine the presence of flammable, hazardous, or radioactive substances. Lockout/tagout controls will be used to prevent uncontrolled releases. Samples will be drawn from holes drilled into the pipes from the top down. Any liquid draining from the holes will be captured and disposed in accordance with the Waste Management Plan. Once pipe interiors are characterized and the proper controls are established, pipes will be sawed in two places. The removed section will be replaced with a temporary plumber's plug, except in the case of Tank 3001-B, at which a new section of pipe will be welded in later to form a continuous pipeline.

Various hoisting and lifting activities will be involved in conducting the tank removals. The technical details of these activities (including lifting equipment, weight, key dimensions and center of gravity, and rigging specifics) are included in the "Hoisting and Rigging Program: Ordinary Lift Plan." Based on an evaluation of the activities to be performed, none of the hoisting or rigging tasks were determined to be critical lifts.

After tank removal, each vault will be filled with a controlled, low-strength material composed of

- $50 \mathrm{lb}$ of Type II cement,

- $600 \mathrm{lb}$ of F-Type fly ash,

- $2400 \mathrm{lb}$ of sand, and

- 50 gal of water.

Before grouting, representative samples of the fly ash, sand, and cement will be analyzed. The grout permeability is expected to be approximately $2 \times 10^{-5} \mathrm{~cm} / \mathrm{s}$, and the compression strength is expected to be approximately 300 psi.

Welding also will be conducted as part of the maintenance action. Appendix A contains the general welding requirements for ORNL. These requirements will be met during all welding tasks. Where applicable, socket weld ends will be welded into place (in accordance with American National Standards Institute standard B16.11). After each weld, a liquid-penetration examination will be conducted to confirm the weld's integrity. 


\subsection{TANK 3001-B}

To remove Tank $3001-\mathrm{B}$, the overlying stairway must be temporarily relocated so that it can continue to serve as a fire exit. The following activities will be conducted as part of removing and relocating the stairs and removing the tank.

1. Using a concrete saw, the posts securing the stairway floor to the underlying pad will be cut from the pad.

2. As specified in the Hoisting and Rigging Plan, the stairway will be rigged and secured to a crane for removal.

3. After the stairway has been rigged, but before it has been moved, the guard rails at the top of the stairway will be cut and modified to reflect the temporary stairway configuration.

4. After the stairway has been cut free, it will be hoisted and placed in the parking lot adjacent to the building. A precast concrete pad will be put in place to support the foot of the stairway.

5. Two "New Jersey Barriers" will be placed on either side of the stairway for protection during its temporary relocation.

6. After the stairway has been removed, the asphalt will be broken up using pneumatic jackhammers, and the resulting asphalt crunches and soil will be excavated using a backhoe. The overburden will be cleared away to allow access to the vault cover for its subsequent removal. The soil will be sampled as it is removed to determine whether it is contaminated. If contaminated, individual scoops of soil will be segregated and boxed for proper disposal, in accordance with the approved Waste Management Plan. The noncontaminated soil will be piled up at the work site and used to backfill and cover the vault.

7. The vault covers will be removed.

8. The inlet and discharge lines will be hot-tapped. Any liquid drained from either line will be containerized and sampled (in accordance with Sect. 2.4), and will be disposed in accordance with the approved Waste Management Plan. The lines then will be cut.

9. Lugs will be welded onto the tank, and the tank will be removed from the vault, capped, wrapped, and placed in a Sealand ${ }^{\mathrm{Tu}}$ container. Any decontamination or sampling needed to meet the waste acceptance criteria of Science Ecology Group, Inc., will be performed.

10. A single-wall, Schedule 40 pipe section will be welded to connect the inlet and discharge pipes.

11. After the pipe has been welded and nondestructive examination (i.e., dye-penetrant testing) is completed, the empty vault will be filled with grout.

12. The vault lids will be replaced before the grout sets. 
13. The concrete landing will be backfilled and reworked. A new concrete pad will be poured to support the stairs. The concrete pad will consist of 3000-psi concrete reinforced with 6-in. $\times 6$-in. $\times 6$-gauge welded-steel wire.

14. The stairs will be reinstalled.

\subsection{TANK 3004-B AND TANK T-30}

The vaults containing these tanks are of similar construction, as are the tanks themselves. Therefore, the same process will be used to remove both tanks. The following activities will be conducted as part of the removal task.

1. The vault covers will be removed.

2. The inlet and discharge lines will be hot-tapped. Any liquid drained from either line will be containerized and sampled (in accordance with Sect. 2.4). The lines then will be cut.

3. The tank will be removed from the vault, capped, wrapped, and placed in a Sealand ${ }^{\mathrm{TM}}$ container. Any decontamination and sampling necessary to meet the waste acceptance criteria of Science Ecology Group, Inc., will be performed.

4. The cut lines will be capped.

5. The Tank 3004-B vault will be grouted full to allow replacement of the vault cover. The Tank T-30 vault will be grouted full to allow the placement of a 6-in., reinforced-concrete cap over the vault.

6. A concrete pad will be poured at the Tank 3004-B vault. The Tank T-30 vault lid will be replaced before the grout sets.

7. The ground surface will be backfilled and reworked. The decorative rocks at Tank 3004-B will be replaced.

\subsection{TANK 3013}

Tank 3013 will be closed in place by cutting all lines and filling the tank with grout. The following activities will be performed to accomplish the work.

1. A silt fence will be erected around and downslope of the site to prevent erosion or runoff during the excavation activities. The silt fence either will be a preassembled fence installed to manufacturer's specifications, or will be constructed to the following specifications.

- Posts will be spaced $6 \mathrm{ft}$ to $10 \mathrm{ft}$ apart.

- A geotextile fabric will be installed to a height of 2 to $3 \mathrm{ft}$ above grade and anchored in a trench 6 in. wide and 6 in. deep. 
- The geotextile fabric will be attached to the posts by staples.

- After installation of the geotextile fabric, the trench will be backfilled.

2. The ground surface around the tank will be hand-excavated to a depth not exceeding $4 \mathrm{ft}$. The slope ratio from the pit will be 1:1. At this depth, all lines leading into the tank will be exposed, with the exception of a 1/2-in. line at a depth of approximately $6 \mathrm{ft}$. The 1/2-in. line is currently isolated from Building 3013.

3. The lines will be hot-tapped, and any fluid will be containerized and sampled. The lines then will be cut. Removed piping will be disposed in accordance with the Waste Management Plan.

4. The tank then will be filled with grout.

5. After the tank has been grouted full, all lines will be welded closed and examined using a dye-penetrant test.

6. The pit will be backfilled with soil, sodded, and restored to original site conditions.

\subsection{SAMPLING AND ANALYSIS}

The purpose of sampling is to characterize the liquid waste produced by removal of the tanks, to achieve proper disposal. This section describes the necessary sampling procedures and the analytical protocols, along with quality control (QC) requirements. It is anticipated that the number of samples needed for the entire task will be four or less, not including appropriate QC samples. Sample identification will be correlate to the tanks sites [e.g., sample identifiers S(3001B), S(3004-B), S(T-30), S(3013)]. All sampling and analysis activities will be documented in the logbook.

\subsubsection{Sampling Procedures}

Upon removal of a tank and as the process lines are being cut, a grab sample of liquid waste will be collected in accordance with ESP-301-1, "Liquid Sampling Using a Dipper." However, the sampling container may be placed in line with the outflow end of the process pipe to collect any residual liquid waste for analysis, thereby eliminating the need for a dipper.

\subsubsection{Analytical Protocols}

Liquid waste samples will undergo screening analysis by a laboratory capable of isotopic confirmation. The following are requirements concerning parameters, method, MDAs, required sample volumes, and containers. 


\begin{tabular}{lccccc}
\hline \multicolumn{1}{c}{ Parameter } & Method & MDA & $\begin{array}{c}\text { Required } \\
\text { sample volume }\end{array}$ & Preservative & $\begin{array}{c}\text { Container } \\
\text { requirements }\end{array}$ \\
\hline Gross alpha & EPA 900.0 & $0.185 \mathrm{~Bq} / \mathrm{L}$ & $2 \mathrm{~L}$ & $\mathrm{HNO}_{3}$ to $\mathrm{pH}<2$ Polyethylene bottles \\
Gross beta & EPA 900.0 & $0.185 \mathrm{~Bq} / \mathrm{L}$ & $2 \mathrm{~L}$ & $\mathrm{HNO}_{3}$ to $\mathrm{pH}<2$ Polyethylene bottles \\
Gamma spectroscopy & EPA 901.0 & $0.936 \mathrm{~Bq} / \mathrm{L}$ & $2 \mathrm{~L}$ & $\mathrm{HNO}_{3}$ to $\mathrm{pH}<2$ Polyethylene bottles \\
\hline
\end{tabular}

Isotopic analyses will be conducted if the following threshold limits are exceeded.

\begin{tabular}{cccl}
\hline Parameter & Exceeding limit & \multicolumn{1}{c}{ Isotopic analysis } & \multicolumn{1}{c}{ Method } \\
\hline Gross alpha & $>0.555 \mathrm{~Bq} / \mathrm{L}$ & ${ }^{238} \mathrm{Pu},{ }^{239} \mathrm{Pu},{ }^{234} \mathrm{U},{ }^{235} \mathrm{U},{ }^{238} \mathrm{U}$, Total Uranium, & EPA 900 Series/ \\
& & ${ }^{237} \mathrm{~Np},{ }^{228} \mathrm{Th},{ }^{230} \mathrm{Th},{ }^{232} \mathrm{Th}$ & HASL 300 \\
Gross beta & $>30 \mathrm{~Bq} / \mathrm{L}$ & ${ }^{90} \mathrm{Sr}$ & EPA 900 Series \\
\hline
\end{tabular}

The sample amounts provided for the original analyses will provide adequate sample for the subsequent isotopic analyses also.

The sample results and MDAs will be reported from the laboratory as Bq/L. These results can be converted to $\mathrm{Ci} / \mathrm{L}$ using the following formulae.

$$
\begin{gathered}
1 \mathrm{Ci}=3.7 \times 10^{10} \mathrm{~Bq} \\
B q / L \times 27=p C i / L
\end{gathered}
$$

In addition, the $\mathrm{pH}$ of each sample will be measured.

\subsubsection{Quality Assurance/Quality Control Samples}

The sample amounts collected for the original analyses will be adequate to conduct the QA/QC analyses also. The QC samples required for analysis will include one duplicate sample.

\subsubsection{Sample Handling}

All samples will be handled in accordance with ESP-505, "Sample Packaging, Transporting, and Shipping." Sample containers will be certified to meet or exceed the EPA standards for cleanliness. Sample labels will be affixed to all sample containers before or at the time of sampling in accordance with ESP-500, "Sample Labeling." To the extent practical, sample bottles will be labeled before filling and will be completed using indelible ink. Sample bottles will contain, as a minimum, the site name, unique sample identification, date/time of sample collection, type of sample (matrix), name of the sampler, sample preservation, and types of analyses to be conducted.

Sample seals will be used to detect tampering after sample collection and before analysis. The seals will be attached to the sample containers so that opening the sample will break the seal. 
Samples will be tracked from time of collection through analysis by a chain-of-custody procedure in accordance with ESP-501, "Sample Chain of Custody."

\subsubsection{Control of Wastes}

The LMES Waste Management Organization will accept liquid waste for treatment under controlled conditions only. As a condition of waste acceptance, the generator of the waste must provide a description of the waste (i.e., matrix and major contaminants), radioisotopes present in the waste, total alpha activity, total beta/gamma activity, and $\mathrm{pH}$.

The processing of collected waste materials is addressed in the Waste Management Plan. Requirements include packaging and labeling of site-specific waste; completion of forms UCN-2109, "Waste Item Description," and UCN-20117, "Waste Certification Statement"; and documentation such as UCN-20116, "Process Knowledge Documentation," supporting waste characterization.

\subsubsection{Data Management}

Data management activities will include generating of the chain-of-custody reports for any sampling events, collecting and reporting the analytical results, and tracking the sample from time of origination, through analysis, until the data are reported. Manual documentation and a flat-file data base (to be used for reporting purposes only) are the data management tools to be used. Any data manually entered into the project data base will undergo a $100 \%$ QC verification. Information that is to be electronically input will undergo $10 \%$ verification. The QC documentation information will be noted on the front page of all hard-copy data entries.

The project Field Manager will collect the necessary information and report the required data to the Oak Ridge Environmental Information System (OREIS) data base within the time frame specified by the OREIS Data Manager. Project diskettes will be processed through the CDM Federal Disk Management System.

\subsubsection{Records Management}

The Field Manager will receive a copy of all field logbooks weekly from the field crew. Logbook copies will be maintained in the project file until the original logbook has been supplied. When the original log sheets are supplied to the project files, the copies will be moved to the record copy area of the Records Management Area. All forms and project documentation regarding the maintenance action will be forwarded by the field crew for inclusion into the project files. The documentation will be assigned a document control number. The ER ORNL Data Management Center (DMC) filing system will be followed and the files will be established accordingly.

At the close of the project, the Field Manager will supply the ER ORNL DMC with an original or best available copy of all required project records. The Field Manager also will supply an electronic copy of the records data base. 
95-096/7913-330/0630 


\section{QUALITY ASSURANCE}

This section is designed to combine management, training, procedures, documentation, and assessments to ensure that the maintenance action is successful and well-documented. Specifically addressed in this section are task management responsibilities, training requirements, field quality assurance (QA)/QC, and records management.

A Quality Assurance Evaluation (Activity No. ENGR-251, QAE No. QAE-X-95-ENGR-251) was completed on March 16, 1995, in accordance with the Quality Assurance Plan for Oak Ridge National Laboratory Environimental Restoration Program [ORNL/ER-225 (Energy Systems 1994)]. The Quality Assurance Evaluation completed by Martin Marietta Energy Systems, Inc. (Energy Systems) program management assigned a Q-Category III to the Inactive Tanks Remediation Program. The four tanks in question have been determined to pose no risk to human health and the environment. However, sample analysis is required to determine proper disposal of any liquid waste produced by removal of the tanks.

A Q-Category III project does not require a formal QA Project Plan, because standard engineering procedures, guidelines, and practices will be sufficient to control the quality-related engineering and construction activities of the project. As a minimum, information pertaining to organizational and functional responsibilities, controlled documents, and quality records will be discussed in this section. Programmatic QA/QC requirements are specified in ORNL/ER-225 (Energy Systems 1994), and in the Environmental Restoration Quality Program Plan [ES/ER/TM-4/R3 (Energy Systems 1993)].

The Maintenance Action Work Plan will be the primary controlling document for this project. The Work Plan will be supplemented by such documents as a Site-Specific Health and Safety Plan, a Readiness Review Plan, a Hoisting and Rigging Plan, and a Conduct of Operations Matrix. Procedural requirements will be specified in ESO:PX483G-01, "Service Contract Specification for Inactive Tanks 3001-B, 3004-B, 3013, and T-30," dated April 19, 1995 (Energy Systems 1995), and their related attachments.

\subsection{ORGANIZATIONAL AND FUNCTIONAL RESPONSIBUITIES}

The organizational structure of the WAG 1 Batch I (Series 1) Inactive Tanks Project Team (shown in Fig. 1.6) is composed of the ORNL ER Program Environmental Safety and Health Manager, the ORNL Facility Manager, the Site Safety and Health Officer and alternate, the ORNL ER Site Project Manager, the ER Waste Management Coordinator, the HAZWOPER Program Coordinator/Safety and Health Evaluation Support Team, the Office of Environmental Compliance and Documentation representative, and the Laboratory Shift Superintendent.

\subsubsection{Project Personnel}

The responsibilities of the Site Safety and Health Officer, the Office of Radiation Protection representative, and other health and safety personnel are described in the Site-Specific Health and Safety Plan. Generally, QA responsibilities of project personnel will include, as a minimum, 
- ensuring that the applicable quality requirements are met;

- ensuring the quality of assigned work;

- ensuring that operating procedures are identified, required, and effectively implemented;

- interacting with the assigned QA Specialist on all quality-related matters; and

- $\quad$ performing self-assessment of assigned project duties.

\subsubsection{Quality Assurance Specialist}

The ER QA Specialist reports on a functional basis to the ER Project Manager, and the Engineering QA Specialist reports on a functional basis to the ORNL Construction Engineer. Each QA Specialist provides advice and recommendations to the ER Program Quality Manager on quality-specific anomalies. For example, the ER QA Specialist's responsibilities are outlined in Sect. 1.5.4 of ES/ER/TM-4/R3 (Energy Systems 1993), and may include

- helping the assigned ER project manager prepare procedures and documents to establish and implement the Quality Program in accordance with this document;

- evaluating the effectiveness of QA activities in the ER Program through scheduled assessments, and reporting the results to the Quality Manager and the responsible ER project manager;

- providing guidance to resolve quality problems, and ensuring that corrective action is taken and appropriately documented in response to occurrence reports, nonconformance reports, etc.;

- helping ER Program management track corrective actions and analyze data pertaining to quality;

- participating in ER Program readiness reviews and as a member of the project team;

- identifying areas in which improvement could benefit the ER Program; and

- initiating stop-work actions when the severity of conditions adverse to quality warrants immediate action.

\subsection{TRAINING REQUIREMENTS}

A team of field personnel will complete the maintenance action. They will include the Field Manager, Site Safety and Health Officer, Office of Radiation Protection representative, and other personnel, as necessary. Their training will be implemented and documented in accordance with ER/C-P1613, "Implementation of ER Training Program Requirements for ER Program Personnel," and the Site-Specific Health and Safety Plan.

The Field Manager is responsible for providing technical direction and oversight to the project team, for providing documentation of the work performed, for ensuring adherence to the procedures and statement of work, and for alerting the ER Project Manager to any variances from approved procedures. 
The Site Safety and Health Officer is responsible for monitoring and enforcing the health and safety procedures addressed in the Site-Specific Health and Safety Plan. The Site Safety and Health Officer is a trained professional having demonstrated field experience in monitoring health and safety in the context of potential standard construction hazards. The Site Health and Safety Officer will interact with the Office of Radiation Protection representative to provide comprehensive health and safety coverage in accordance with the Site-Specific Health and Safety Plan, as appropriate.

The Site-Specific Health and Safety Plan for this project describes the training required for the field crew. Each member will have received 40-hour Occupational Safety and Health Administration (OSHA) and Radiation Worker I and II training before commencing work. The Field Manager will have completed 8-hour OSHA Supervisory Training. At least one person onsite will have current first-aid and cardiopulmonary resuscitation certification. Section 10.1 of the Site-Specific Health and Safety Plan details the personnel training requirements.

\subsection{FIELD QUALITY ASSURANCE/QUALITY CONTROL}

The quality of work performed in the field is evaluated by the adherence to approved plans and procedures. This section summarizes field $\mathrm{QA} / \mathrm{QC}$ requirements for activities such as maintaining the field logbook, decontaminating equipment, and calibrating field instruments.

\subsubsection{Field Logbooks}

Field logbooks will be used as the primary documentation of field activities. Two logbooks will be maintained for this action-one for field management records and one for site health and safety records. The logbooks will be maintained as controlled documents.

In general, logbooks will be water-resistant, hard-cover, and bound with lined and paginated sheets. Entries will be printed or written legibly in black waterproof ink. The cover will include the project name and number, name of the contractor, name of the primary user of the logbook (e.g., the Field Manager, the Site Health and Safety Officer), a document control number, an entry for the start date of the use of the logbook, and an entry for the final or closing date. This information will be reiterated on the inside cover of the logbook. The first two or three pages will be dedicated as a Table of Contents that will identify the page locations of key entries (e.g., significant events, data tables, serial numbers of equipment).

Daily entries will identify the date, the time (in military units), task personnel and visitors present, and weather conditions upon beginning activities. Entries will describe the activities to be performed, the equipment used, significant occurrences, and any variances from established

procedures. Specifically, the logbook will record sufficient detail to allow reconstruction of daily events by an independent observer. Logbooks are considered controlled documents, and are subject to the project's records management system described in Sect. 3.4.

\subsubsection{Decontaminating Equipment}

All equipment used on the project will be inspected and decontaminated, if necessary, in accordance with the Site-Specific Health and Safety Plan. Decontamination of all field sampling 
equipment shall be performed in accordance with ESP-801, "Cleaning and Decontaminating Sample Containers and Sampling Devices." However, no equipment is anticipated to require decontamination before or after use during this action. Equipment such as backhoe, auger rig, and shovels will be inspected for external contamination (i.e., leaks or excessive grease) before entering the site. None of the equipment is anticipated to come into contact with contaminated soil or water.

\subsubsection{Calibrating Field Instruments}

All field instruments, including those for health and safety monitoring, will be identified and their respective serial numbers will be recorded in the Field Manager's logbook. Each instrument will be complete with documentation certifying calibration, and will be response checked at the start and end of each work day using a certified source to ensure that instruments are operating within specified ranges. The calibration checks will be completed in accordance with Implementing Procedure ESS.12.0, "Control of Measuring and Test Equipment."

\subsection{RECORDS MANAGEMENT}

A QA records system will be designed, implemented, and enforced in accordance with Sect. 4.2 of ES/ER/TM-4/R3 (Energy Systems 1993) and with Implementing Procedure ESS.17.0, "Quality Assurance Records." ER Program managers and project managers are responsible for identifying any QA records and for requiring their inclusion in the records system. The applicable work plans, specifications, procurement documents, test procedures, operation procedures, or other documents will specify the records to be generated, supplied, or maintained by or for LMES. QA records may be distinguished from project records by stamping or identification (e.g., "Record Copy") in the records index.

Section 2.2.17 of ORNL/ER-225 provides additional requirements for record copy documents. For example, test and inspection records and results to be maintained as record copy material will be designated in the construction project test summary. The ER Program manager shall receive a copy of all record copy materials generated by the project. The ER Program manager shall be responsible for transmitting all applicable documents to the DOE-Oak Ridge Operations ER Administrative Record.

\subsection{PROGRAMMATIC QUALITY ASSURANCE/QUALITY CONTROL}

Before any work begins, the project team will conduct a readiness assessment in accordance with the Readiness Assessment Plan. During a field effort, field personnel and QA personnel are responsible for properly implementing procedures and for controlling and improving the quality of all work. Responsibilities of field and QA personnel are described in the following paragraphs. Also, any unapproved variance from regulations, approved requirements, or procedures is considered a nonconformance. The procedure for documenting nonconformances and reconciling them is described in the following paragraphs. 


\subsubsection{Readiness Assessment}

Before mobilization, a readiness assessment will be conducted to determine the status of the preparation necessary to complete the task. The assessment will be completed in accordance with ER/C-P1610, "Conducting Project Readiness Reviews," which covers such items as approved plans, clearances, site access, other applicable procedures, training, assembly of materials and equipment, waste management, health and safety, and QA.

\subsubsection{Responsibilities of Field Personnel}

Field personnel will review all applicable procedures, plans, and policies. Field personnel are responsible for the quality of the project, which will be evaluated through self-assessments and scheduled independent surveillances and/or audits.

\subsubsection{Responsibilities of Quality Assurance Personnel}

LMES QA personnel and DOE QA personnel may conduct independent QA assessments in the form of audits or surveillances periodically during the project. The assessments will focus on adherence to all procedures, regulations, and policies, including programmatic policies not addressed in this plan but included in ES/ER/TM-4/R3 (Energy Systems 1993) and/or ORNL/ER225 (Energy Systems 1994).

\subsubsection{Nonconformances}

A nonconformance is a variance from regulations, approved requirements, or procedures that adversely affects safety, durability, performance, or any other basic objective for the quality of the work performed. A nonconformance is not to be confused with a minor or major change that is approved as a variance to a requirement before its implementation. Nonconformances can be identified by field personnel and by QA personnel. Nonconformances identified through project team self-assessments, LMES QA assessments, or DOE QA assessments will be handled in accordance with approved procedures.

If a nonconformance is identified during the action and can be brought into conformance immediately, the problem may be rectified by verbal instruction and the entire event noted in the field logbook. If a nonconformance is identified after the procedure is completed, the problem will be documented on a nonconformance report by the person who identified the condition. If a nonconformance report is required, the report will be initiated and handled in accordance with Implementing Procedures ESS.15.1, "Control of Nonconforming Items," and ESP.15.2, "Control of Nonconforming Items." The system is designed to ensure that nonconformances will be documented and actions taken to mitigate and correct problems.

\subsubsection{Corrective Action}

If a nonconformance is identified, formal corrective action may be required to rectify the situation. If corrective action is required, a corrective action request will be prepared, completed, processed, and implemented by QA personnel in accordance with Implementing Procedures ESS.16.0, "Corrective Action," and ESP.16.1, "Corrective Action." 


\section{BEST MANAGEMENT PRACTICES}

Section 304(e) of the Clean Water Act enables the EPA Administrator to control point source releases of pollutants. The National Pollutant Discharge Elimination System requires that facilities having the potential to release pollutants to the waters of the United States will submit a Best Management Practices Plan, as specified in $40 C F R 125$, Subpart $\mathrm{K}$, as a part of the discharge permit application.

According to the LMES Environmental and Waste Management Policy, ESH-14 (Energy Systems 1985a), "It is company policy to establish and to maintain waste management, pollution control, and surveillance programs which are consistent with the company and DOE policy and which meet the requirements of federal, state and local regulations to assure that installation personnel, the general public, and the environment are protected against hazardous pollutants."

To meet these requirements, the following best management practices will be used at WAG 1.

\subsection{SPILL PREVENTION AND CONTROL}

Spill Prevention Control Countermeasures and Contingency Plans for Oak Ridge National Laboratory (Energy Systems 1990) provides details concerning roles and responsibilities of personnel responding to releases of oils or hazardous substances. Only that portion directly related to activities during the WAG 1 inactive tanks remediation is summarized here.

The Energy Systems Spill Prevention Control Countermeasures and Contingency Plans for Oak Ridge National Laboratory (1990) require that all possible precautions be taken to minimize the likelihood of a spill and, in the event of a spill or release, that they are safely contained and recovered in a manner that best ensures personnel safety and protection of the environment.

All tanks having capacity greater than 5 gal are required to bear the appropriate hazardous identification placards (diamonds), as identified in the National Fire Protection Association Code (NFPA-704) (1961). Tanks, drums, and other containers of hazardous or toxic material such as cleaning solvents, some detergents, or degreasers will require secondary containment while stored on-site. Guidelines for design and construction of hazardous-material-storage tanks and secondary containment are specified in Design Standards for Hazardous/Toxic Waste and Material Storage Tanks, Dikes, and Transfer Stations, Y/TS-104 (Energy Systems 1985b).

All heavy equipment and mechanical equipment will be maintained in good repair to minimize the release of engine, transmission, or other oils through slow leaks. Idle equipment will be parked as far away from stream beds or drainage pathways as is practical. Repairs to correct any substantial leaks will be effected as soon as possible.

Fueling operations will be performed with care to prevent inadvertent small releases. It is expected that material spilled by contractors, if any, will be reported to LMES and cleaned up as soon as possible, placed in appropriate containers, and disposed of in accordance with Waste Management Operations procedures. 
If a spill occurs at the WAG 1 site, all safe and practical methods available should be used to prevent material from entering streams, creeks, or springs. Spill control kits containing absorbent material will be provided at the site. Absorbent pillows, temporary earthen dikes, or other readily available means should be employed, as appropriate, without risking personnel safety.

All potentially contaminated samples and sample purge water must be properly stored in labelled containers to prevent spillage. During excavation for seep weirs, the material removed will be monitored using portable radiation detectors and with portable ionization detectors for volatile organics. If contaminated materials are detected, they will be segregated and stockpiled on polyvinyl sheeting for later use as backfill on the project. The stockpiled material will be covered to prevent the spread of contamination by dispersion or leaching by rainwater.

\subsection{GOOD HOUSEKEEPING PRACTICES}

Good housekeeping practices will be observed by all personnel present at the field sites at all times. Paper trash and refuse will be contained, collected, and disposed of at an appropriately permitted facility. All rinse water containing additives of any sort (e.g., soap, degreasers, cleaning agents) will be collected, contained, and disposed of in accordance with the appropriate wastedisposal procedure. Trucks hauling material on- and off-site will not be overfilled. Loose debris will be contained within the vehicles to prevent littering of highways and haul roads. Brush and trash will be removed from drainage paths and creeks.

Fueling operations will be conducted so that small fuel/oil releases are contained and cleaned up as soon as possible. All possible precautions are to be taken to minimize discharge of fuel, oil, lubricants, grease, and other hydrocarbons.

Suitable staging areas will be provided and used to support the waste management activities of the project, including staging, handling, and packaging facilities, as appropriate for the specific conditions encountered. The staging areas will be established and controlled to prevent the dispersal of radioactive or hazardous contamination, if encountered, to the surrounding environment.

\subsection{INSPECTIONS FOR ENVIRONMENTAL COMPLIANCE}

Periodic site inspections during the field activities will be conducted by LMES to confirm compliance with all environmental regulations and policies, including those set forth in this Maintenance Action Work Plan.

Best management practices to be inspected for may include, but are not limited to,

- condition of erosion control structures, including

- the silt fence,

- drainage ways,

- any gully formation, 
- any areas that require seeding, and

- replacement of hay/straw bales;

- general housekeeping on-site;

- $\quad$ evidence of poor fueling practices;

- evidence of leaking tanks or equipment;

- inspection of records, including those showing types and quantities of hazardous/toxic materials on-site; and

- inspection of safe storage of hazardous/toxic materials (i.e., materials are compatible, and diked if required).

A written record, including the date and findings of the inspection and notification of appropriate party.

\subsection{SEDIMENT AND EROSION CONTROL MEASURES}

A primary component of best management practices is to provide effective erosion and sediment control. Erosion is a natural phenomenon that is greatly increased by the removal of existing vegetation and the introduction of cuts and fills. Excessive erosion causes physical damage in the watershed as a result of increased water velocity. Unchecked sediment can increase turbidity and suffocate streambed flora and fauna under a blanket of silt. Erosion controls placed during the field activities phase will minimize soil movement. Several excellent sources are available that describe best management practices for erosion and sediment control (EPA 1972, EPA 1973, U.S. Department of Agriculture 1974, U.S. Department of Transportation 1978).

The following actions will be taken during the field activities phase of the project, to lessen the environmental impact of erosion.

- On steep slopes, if any, erosion control matting will be placed to reduce the potential for erosion.

- In accordance with U.S. Department of Transportation guidance, silt fences, sediment traps, and ditches will be installed immediately after tree clearing, if any, and before grubbing, scalping, or filling.

- Periodic inspections will be conducted to verify that silt fencing is in operational condition.

- Hay/straw bales will be placed as needed.

- Seeding and mulching will immediately follow the development of each construction segment. 


\section{HEALTH AND SAFETY}

A Site-Specific Health and Safety Plan (ORNL/ER-226, 01-226/0009-0695; LMES 1995) has been prepared for this project. The Site-Specific Health and Safety Plan adheres to the requirements of the health and safety plan for the ER Program at ORNL (ORNL/ER-226), and follows the checklist outline specified in Attachment B of that document. 


\section{REFERENCES}

Energy Systems (Martin Marietta Energy Systems, Inc.) 1985a. Environmental and Waste Management Policy. ESH-14. Oak Ridge, Tennessee.

Energy Systems (Martin Marietta Energy Systems, Inc.) 1985b. Design Standards for Hazardous/ Toxic Waste and Materials Storage Tanks, Dikes and Transfer Stations. Y/TS-104. Oak Ridge Y-12 Plant, Oak Ridge, Tennessee.

Energy Systems (Martin Marietta Energy Systems, Inc.) 1990. The Spill Prevention Control Countermeasures and Contingency Plans for Oak Ridge National Laboratory. Oak Ridge, Tennessee.

Energy Systems (Martin Marietta Energy Systems, Inc.) 1993. Environmental Restoration Quality Program Plan. ES/ER/TM-4/R3. Oak Ridge, Tennessee. September.

Energy Systems (Martin Marietta Energy Systems, Inc.) 1994. Quality Assurance Plan for Oak Ridge National Laboratory Environmental Restoration Program. ORNL/ER-225. Prepared by Gilbert/Commonwealth, Inc., Knoxville, Tennessee. June.

Energy Systems (Martin Marietta Energy Systems, Inc.) 1995. Service Contract Specification for Inactive Tanks 3001-B, 3004-B, 3013, and T-30. ESO:PX483G-01. Oak Ridge National Laboratory, Oak Ridge, Tennessee. April 19.

Energy Systems (Martin Marietta Energy Systems, Inc.) 1994. Health and Safety Plan for the Environmental Restoration Program at Oak Ridge National Laboratory. ORNL/ER-226. Oak Ridge National Laboratory, Oak Ridge, Tennessee. August.

EPA (U.S. Environmental Protection Agency) 1972. Guidelines for Erosion and Sediment Control Planning and Implementation. EPA-R2-72-015. August.

EPA (U.S. Environmental Protection Agency) 1973. Comparative Costs of Erosion and Sediment Control. Construction Activities. EPA 430/9-73-016.

EPA (U.S. Environmental Protection Agency), Region IV, U.S. Department of Energy, and Tennessee Department of Environment and Conservation 1994. Federal Facility Agreement for the Oak Ridge Reservation. May 19.

LMES (Lockheed Martin Energy Systems, Inc.) 1995. Specific Application Checklist for Maintenance Action for Waste Area Grouping 1 Inactive Tanks 3001-B, 3004-B, T-30, and 3013 at Oak Ridge National Laboratory, Oak Ridge, Tennessee. 001-226/0009-0695. Prepared by CDM Federal Programs Corporation, Oak Ridge, Tennessee.

National Fire Protection Association. 1961. Standard System for the Identification of the Fire Hazards of Material. NFPA-704. 
U.S. Department of Agriculture. 1974. Erosion and Sediment Control Handbook for Urban Areas and Construction Sites in Tennessee.

U.S. Department of Transportation. 1978. Best Management Practices for Erosion and Sediment Control. December. 


\section{APPENDIX A}

\section{WELDING SPECIFICATIONS}




\section{GENERAL WELDING REQUIREMENTS}

\section{PART 1: GENERAL}

\subsection{SUMMARY}

A. Section includes: Welding fabrication and construction activities occurring both on-site and off-site. These requirements apply to pipe welding when invoked by other technical sections or when drawings require fabrication to codes addressed by this document. These requirements do not apply to work on ASME-stamped components, AWWA tanks, or API tanks.

B. The off-site welding requirements are specified in Part 2 of this section.

C. For on-site welding, Part 3 of this section identifies the welding program requirements and responsibilities. The on-site program including welding procedure specifications, weld joint details, welder qualifications requirements, and a filler material control procedure necessary to comply with this section are contained in Div. $18 \mathrm{~B}$ which is available from the CM.

D. Approval of a Contractor's welding procedures and welders for on-site welding may be granted for either of the following:

1. The Contractor wishes to use a welding process not included in Div. 18.

2. The majority of the fabrication is off-site, and the Contractor will use the welding procedures and welders approved for off-site welding for the on-site installation welding.

\subsection{RELATED SECTIONS}

A. Section 01120, Safety Requirements for Welding and Cutting (Burning) and Incidental W'elding.

1.03 REFERENCES

A. AWS QC-1, Specification for Qualification and Certification of Welding Inspectors, 1988 Edition.

B. ASME Boiler and Pressure Vessel Code, Sect. IX, Welding and Brazing Qualifications, 1992 Edition.

C. ASME Boiler and Pressure Vessel Code, Sect. V, Nondestructive Examination, 1992 Edition.

D. ASME Boiler and Pressure Vessel Code, Sect. II, Part C, Material Specification, 1992 Edition.

E. Technical Specification Div. 18B, On-Site Welding, June 1993 Edition (available on request).

F. ASME B31.3, Chemical Plant and Petroleum Refinery Piping, 1993 Edition.

G. ASNT, Recommended Practice SNT-TC-1A, December 1988 Edition. 


\subsection{DEFINITIONS}

A. Engineer: The Facilities Manager's engineering organization responsible for the design of the system, component, or structure.

B. Examination: Nondestructive testing performed on a weld to determine its compliance with established acceptance standards. A visual examination evaluates specifically listed attributes to established acceptance criteria.

C. Examiner: A qualified individual who performs examination functions.

D. Faying Surface: The mating surface of a member which is in contact or in close proximity with another member to which it is to be joined.

E. Inspection: Oversight function of welding provided by the Facilities Manager or $\mathrm{CM}$ to ensure that requirements applicable to welding are satisfied. A visual inspection evaluates such things as configuration, appearance, and location and is useful in identifying areas requiring further examination.

F. Inspector: A qualified individual who is designated to perform welding inspection functions.

G. Monitor: To scrutinize or check systematically to ensure compliance with requirements.

H. On-Site: Welding activities which occur at any one of the DOE facilities managed by the Facilities Manager, including ORNL, K-25, and Y-12 at Oak Ridge TN.

I. Off-Site: Welding activities which occur outside the boundaries of the DOE facilities operated by the Facilities Manager such as vendor shop fabrication of welded structures and equipment.

J. Procedure Qualification Record (PQR): Written documentation of the qualification of a weld procedure by examination and testing of physical weld specimens made using the weld procedure.

K. Performance Qualification Test (PQT): Standard performance test(s) which a welder must successfully pass in order to be qualified to weld. The requirements for these tests are based on a qualified WPS and establish a specific range of essential variables the welder is qualified for.

L. Welder Performance Qualification (WPQ): The record which documents a welder's successful completion of a performance qualification test and establishes the range of variables the welder is qualified for.

M. Welding Procedure Specification (WPS): A written document which establishes the essential, nonessential, and supplementary essential (when required) variables for welding and provides direction to the welder for making production welds to ensure compliance with requirements. 


\subsection{SUBMITTALS}

A. Off-Site Welding

1. Approval of the following are required prior to welding.

a. Welder/welding operator qualification records, including evidence of updates.

b. Welding procedures and PQRs.

c. Visual examination and nondestructive examination procedures.

d. Qualifications of examination personnel.

2. Submit weld examination reports prior to delivery of the equipment.

B. On-Site Welding

1. Submit the following for approval when the Contractor requests approval to use their procedures on-site.

a. Welder/welding operator qualification records.

b. Weld procedures and PQRs.

2. Submit one copy of the welder qualification request forms (Attachment A) and welder process usage form (Attachment B) for information as described on the form.

1.06 QUALITY ASSURANCE

A. Welding to this specification requires that welders, welding procedures, inspectors, and inspection procedures meet the requirements specified in Part 2 or Part 3. For on-site welding, inspections are performed by Facilities Manager inspectors using Facilities Manager procedures. For off-site welding, the Contractor performs inspections/examinations using personnel and procedures approved by the Facilities Manager.

\section{PART 2: PRODUCTS}

\subsection{MATERIAL REQUIREMENTS}

A. Welding Rods and Electrodes

1. Verify filler materials delivered are legibly marked in accordance with the General Requirements for each specification listed in AWS or the ASME Boiler and Pressure Vessel Code, Sect. II, Part C, Material Specifications.

2. Verify bare filler material is identified with the applicable classification and/or specification numbers and is attached to each rod, strip, coil, or spool. Label each end of 36-in. rods. 
3. Control, handle, and identify welding rods and electrodes at all times to avoid material degradation and to ensure they are identifiable as acceptable material until the material is consumed in the welding process.

a. Unless otherwise specified by the Facilities Manager, store and handle low-hydrogen electrodes in accordance with AWS D-1.1.

B. Base Material

1. Control base material and the marking of cut material to ensure the material is identifiable and traceable to applicable documentation when required by the Technical Specification or Contract.

C. Welding Equipment for On-Site Welding at X-10

1. For welded systems placed under ground or in direct contact with low resistance materials having contact with the ground, in addition to OSHA, follow the requirements of Attachment D. Welding Machine Requirements for Field Welding.

\subsection{OFF-SITE WELDING REQUIREMENTS}

\section{A. Welding Procedures}

1. Prepare written welding procedures and qualify them for the scope of welding required in accordance with the applicable code in para. 3.01 .

B. Qualification of Welders

1. Qualify welders and welding operators to weld using the appropriate approved and qualified welding procedure(s). Submit records of qualification, including updates, required by the applicable code for the procedure. The -welder qualification requirements and limits of qualification are those of the code for which the procedure is qualified.

2. Written approval of the qualification records is required prior to welding.

C. Welder Stamps

1. The Contractor assigns each welder or welding operator a unique identification symbol. Welders use this symbol to identify each weld, either by stenciling the symbol adjacent to the weld or by records traceable to the weld joint.

\subsection{EXAMINATION OF WELDS}

A. The Contractor is responsible for the performance of specified weld examinations. These examinations may be performed by Contractor personnel or by an outside qualified examination service. Provide the following for examination of welds made off-site:

1. Examination personnel certification requirements are identified in para. 3.03 . 
2. Written weld examination procedures in accordance with the applicable construction code in Part 3.

3. Examine welds in accordance with Part 3.

4. Welds are subject to inspection by the Facilities Manager and/or the CM. The Facilities Manager or CM may request additional weld examinations on any neeld to establish the quality of the weld. The Facilities Manager reserves the right to accept, reject, or demand removal of welcs which are interpreted to be in violation of this specification.

\section{PART 3: EXECUTION}

\subsection{General Welding Requirements}

A. Make groove and butt welds complete joint penetration and continuous uniess specified atherwise by the engineer. Backwelding of groove welds is acceptable. Do not make welds smaller or shorter than specified by design requirements and indicated on drawings, and do not make them substantially larger or longer than specified without the approval of the engineer. Do not change the location of welds without the approval of the engineer.

B. Pipe Welding

1. Weld piping systems in accordance with ASME B31.3.

a. Use the gas tungsten arc process for welds in the following materials:

1) butt welds in piping $11 / 2$-in. nominal pipe size and smaller,

2) the root pass of stainjess steel piping,

b. Purge the back side of the weld for stainless steel materials until a minimum of $3 / 16$-in. material thickness separates the weld from the back side of the weld.

c. Use low-halogen grinding wheels, flapper wheels, tapes, cleaning fluids, and temperature indicating crayons on stainless steel materials.

d. Do not use copper or aluminum as temporary backing for pipe welding.

e. Do not use backing rings unless permitted on the drawing or in the piping specification.

f. Do not use the SMAW, FCAW, or SAW process for root pass welding of stainless steel piping welds.

g. GMAW with short circuiting transfer is prohibited for pipe welding. 


\section{A. Operational Control}

1. Division 18, Welding, implements the method of accomplishment for on-site welding and therefore is the Government's on-site welding specification which applies uniess otherwise approved by the Facilities Manager. To be in full compliance with the references in Part 1 . welding must be within the operational control of each organization using it. This may be achieved by each organization describing in their quality control program or adopting by reference to this section the following elements.

a. Each organization using Div. 18, Welding, may request the Facilities Manager's Facility Design Systems Staff to make changes. Identify the section number and the suggested change. General comments that the specification is unacceptable will be renurned for specific changes.

b. The Facilities Manager, CM, and each contractor reviews and concurs with Div 18 .

c. The CM and each Contractor records acceptance of each WPS to be used by signing a copy of the example form inciuded in Attachment C. These forms are available at the Y-12 weld test shop and must be completed prior to testing welders or performing production n'elding. The weld test shop keeps a permanent record of these completed forms.

B. General Responsibilities

1. Facilities Manager

a. The Facilities Manager manages and operates welder qualification facilities for the Government.

b. The Facilities Manager maintains a comprehensive set of qualified on-site WPSs and PQRs for on-site welding.

c. The Facilities Manager manages welding activities of its forces and the work of its vendors.

d. The Facilities Manager provides inspection/examination and surveillance activities for welds made on-site.

\section{2. $\mathrm{CM}$}

a. The $C M$ provides management of $C M$ and Contractor welding activities and coordinates the Contractor interface with the Facilities Manager for: weld procedure requalification, welder qualifications, and weld examinations.

\section{Contractor}

a. The Contractor is responsible for providing welding services in full compliance with the applicable code, contract, technical specifications, design drawings, and all other specified design documents. 
b. The Contractor is responsible for requalification of on-site weld procedures when required by the applicable codes.

C. Welding Procedures

1. The elements necessary to achieve qualified welding procedures are summarized belou. Comprehensive sets of on-site WPSs are provided in other sections as follows:

a. 18350 , Piping Welding Procedure Specifications (Div. 18B).

2. General

a. Use Div. 18B WPSs for on-site welding unless otherwise approved by the Facilities Manager.

b. The following documents located in Div. 18B, used in appropriate combination, constitute a qualified welding procedure.

1) WPS (Sect. 18350).

2) General Welding Requirements referenced by the WPS (Sect. 18310).

c. The PQRs referenced on the WPS.

3. Facilities Manager and CM

a. Accomplish on-site welding using Div. 18B weld procedures. These procedures will be qualified in advance by the Facilities Manager and $C M$ as required to be compliant with the applicable construction/welding codes. The Facilities Manager will provide copies of the $\mathrm{PQRs}$ to the $\mathrm{CM}$ and/or the Contractor as is necessary for their acceptance of the WPS.

4. Contractor

a. When possible, uses the prequalified (shared) on-site welding procedures as allowed by ASME B31.3, para. 328.2.2. The Contractors signature on Atrachment $C$ asserts that he accepts the procedure without requalification. For ASME B31.3 shared procedures, the Contractor must identify at all times one welder whose qualification was tested by bend tests.

b. For all other procedures, the Contractor requalifies the existing weld procedure at the Facilities Manager weld test shop or submits PQRs which support the full range of the WPS in Div. 18. The Contractor's PQRs are entered on Attachment C. The Contractor signs the form accepting the WPSs and PQRs. Notify the CM $48 \mathrm{~h}$ in advance for qualification testing.

c. If a weld is identified not covered by this specification, notify the Facilities Manager/CM so that procedures can be provided. 
5. Exception

a. When specifically approved by the Facilities Manger, the Contractor submits its own written weld procedures and $\mathrm{PQRs}$ for approval to be used for on-site welding.

D. Weld Joint Details

1. Use the piping weld joint details specified on the welding procedure specification unless otherwise specified on the construction drawings. For on-site welding, weld joint details are provided in Sect. 18370 of Div. 18B.

\section{E. Welder Qualifications}

1. The key elements necessary to achieve qualified welders and welding operators are summarized below. The detailed administrative requirements necessary to achieve compliance arith the applicable codes are provided in Sect. 18360 of Div. 18B. Each organization performing neelding is responsible for instructing their welders in the approprpiate general welding requirements in Sects. 18310 and 18600.

2. Facilities Manager

a. Provides welder qualification services to the $C M$ and the Contractor at the $Y-12$ aeld test shop.

b. Provides welder qualification records to the $\mathrm{CM}$ and Contractor and assigns a unique identification number to each qualified welder.

c. Maintains a central data base of welders qualified to perform on-site welding and issues a listing of currently qualified welders on a monthly basis to the CM.

d. Performs independent laboratory test functions such as guided bend tests for the $C M$ and Contractors qualifying welders to the requirements of this program, and enters the results on a welder qualification test record.

e. Performs the visual inspection/examination required by the PQT, documents the results on the welder qualification test record, and signs the record as the inspector for the risual.

3. $\mathrm{CM}$ and Contractor

a. Responsible for coordinating the welder qualification tests for their welders with the $Y-12$ weld test shop as follows:

1) Notify the Facilities Manager $48 \mathrm{~h}$ in advance for qualification tests of individual welders by submitting for information one copy of the form in Attachment $A$ to the CM.

2) Positively identify each welder or welding operator. 
3) Accept in ariting the qualification records of their welders qualified at the $Y-12$ weld test shop.

4) Provide the Facilities Manager with a record of welder process usage by filling out Attachment $B$ and submitting for information one copy to the $Y^{\prime}-12$ w'eld test shop.

b. May designate a responsible individual to oversee the qualification of their welders and cosign test and inspection results.

\section{Exception}

a. When specifically approved by the Facilities Manager to use their procedures, the Contractor submits welder certification records for approval for welders to be used for on-site welding.

F. Weld Execution

1. Each organization performing welding on-site is responsible for the following:

a. Providing welding services in full compliance atith the applicable code, contract, technical specifications, design drawings, and other specified design documents.

b. Ensuring that the specified weld procedure is qualified for the application and that the welder(s) are currently qualified for the procedure and for the specific range of welds to be made.

1) The Facilities Manager will specify welding procedures to be used. Notify the Facilities Manager for resolution any siruations in which weld procedures are not qualified for the full range of welding, or if materials are required for which a procedure does not currently exist.

c. Requesting weld inspection'examination services from the Facilities Manager at least $24 \mathrm{~h}$, whenever possible, in advance of the needed service.

d. Maintaining project records required by the specification for base materials and filler materials used in construction until completion of the project, at which time the records will be delivered to the Facilities Manager for storage.

e. Identifying completed welds using welder identification numbers assigned by the Facilities Manager.

f. Providing weld maps shoxing weld locations when Certified Material Test Reports are required by the Technical Specification or contract. Identify weld records, inspection reports, and radiographs with the assigned weld numbers.

g. Repairing welds that fail acceptance standards. 
G. Pipe Welding Procedures

1. Select a welding procedure specification from Table 18100-1. The WPSs are provided in Sect. 18350 which is available upon request.

2. GT88-1(PP) and SM88-1(PP) may be used (shared) by the CM or Contractor. without requalification, as allowed by ANSI B31.3. The remaining WPSs in Sect. 18350 require qualification by the $\mathrm{CM}$ and/or the Contractor prior to use. Once qualified by a Contractor. the procedure may be used on-site by that Contractor indefinitely without further requalification.

3. Weld pipe supports using one of the pipe welding WPSs from Sect. 18350 for the materials specified in the technical specification.

Table 18100-1

\begin{tabular}{ll}
\hline Welding procedure & Application \\
\hline
\end{tabular}

Stainless Steel Piping/Tubing

GT88-1(PP)

All sizes

GT88-1(PP)

Butt Welds Greater than 1 1/2 NPS

SM88-1(PP) (See para. 3.01.C.1)

H. Inspection/Exarnination

1. The Facilities Manager will provide the following:

a. Weld inspection/examination services required by the specifications. This does not relieve the Contractor from complying with other requirements of the code.

b. Select welds to inspect/examine as required by this specification.

c. Interpret the results of weld inspections/examinations and accept or reject inspected/examined welds.

d. Prepare and file inspection/examination reports.

\subsection{EXAMINATION PERSONNEL CERTIFICATION REQUIREMENTS}

A. Personnel performing nondestructive testing other than visual shall be currently certified in accordance with SNT-TC-1A. Only individuals certified for NDT Level I and working under the supervision of an NDT Level II or III or individuals certified as NDT Level II or III may perform nondestructive testing to this specification. 
B. Personnel performing visual examination of welds shall be currently certified either as $\mathrm{A} A \mathrm{~W} S$ CWI or in accordance with the requirements of SNT-TC-1A as in Item 1. or work u.der the direct supervision of an SNT-TC-1A Level II, III, or CWI. If certified to SNT-TC-1A. satisfy the training and experience requirements entirely by time spent in weld examination relates work.

\subsection{EXAMINATION OF PIPING WELDS}

A. Required Examinations

1. Perform a final visual examination of all welds in accordance with ASME B31.3, para. 341.4.2.

2. Examine fully by radiography all circumferential butt and miter groove welds in accordarce with ASME B31.3, para. 344.5. Include at least $11 / 2$ in. of the longindinal welds which intersect the circumferential or miter groove welds in those radiographed.

B. Acceptance

1. The acceptance criteria of ASME B31.3, para. 341.3.2, and Table 341.3.2A for nomal fluid service apply for visual and radiographic examination. Incomplete penetration identified by radiography is unacceptable.

\subsection{REPAIR}

A. The Contractor is responsible for the repair or replacement and reexamination of rejected welds.

\section{END OF SECTION}




\section{WELDER QUALIFICATION REQUEST REQUIREMENTS}

MMES, MK-Ferguson, and Contractors request welder or welding operator qualifications on this form.

1. The welder's supervisor fills out and signs the form.

\section{CONTRACTOR}

Sends the form to MK-Ferguson's Welding Engineer $48 \mathrm{~h}$ in advance (when practical) of the need for qualification testing.

MK-Ferguson's Welding Engineer or his designee signs the form and sends it to the Y-12 Weld Test Shop at least $24 \mathrm{~h}$ in advance (when practical) of the welder.

The welder reports to the weld test shop. The supenisor or company designee signs the Welder Qualification Test Record form at the completion of the test. If the contractor will be sharing Weld Procedure Specifications as allowed by Sect. 18310. the supervisor or company designee designates a welder to be qualified by bend tests.

\section{MK-FERGUSON}

MK-Ferguson's welding engineer or his designee signs the form and sends to the $\mathrm{Y}-12$ Weld Test Shop at least $24 \mathrm{~h}$ in advance (when practical) of the welder.

Welder reports to the weld test shop. MK-Ferguson's welding engineer or designee will witness the test and sign the Welder Qualification Test Record form. If the CM will be sharing Weld Procedure Specifications as allowed by Sect. 18310, designates a welder to be qualified by bend tests.

\section{MMES}

The supervisor sends the form to the Weld Test Shop $24 \mathrm{~h}$ in advance (when practical) of the need for qualification testing.

2. The welder performs the Performance Qualification Tests requested. These tests will be witnessed by the Weld Test Shop test supervisor/welding inspector. The responsibilities are described in Div. 18, Welding, Sect. 18100 and Sect. 18260, 18360, or 18460 as appropriate.

3. The test superisor/welding inspector fills out the Welder Qualification Test Record form at the conclusion of the tests.

4. The test supervisor/welding inspector signs the form for MMES welders. The company representative signs the record for their welders.

5. The original records are filed at the Weld Test Shop for MMES weiders. For MK-Ferguson and Contractor welders, the original is sent to the employer and a copy is filed at the Y-12 Weld Test Shop.

6. The welder's qualification information is added to the welder qualification data base which is distributed a minimum of once each month. 


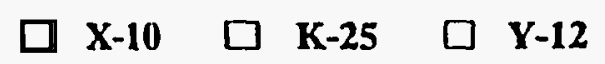

FILI. OUI HOORM IN IIIACK INK

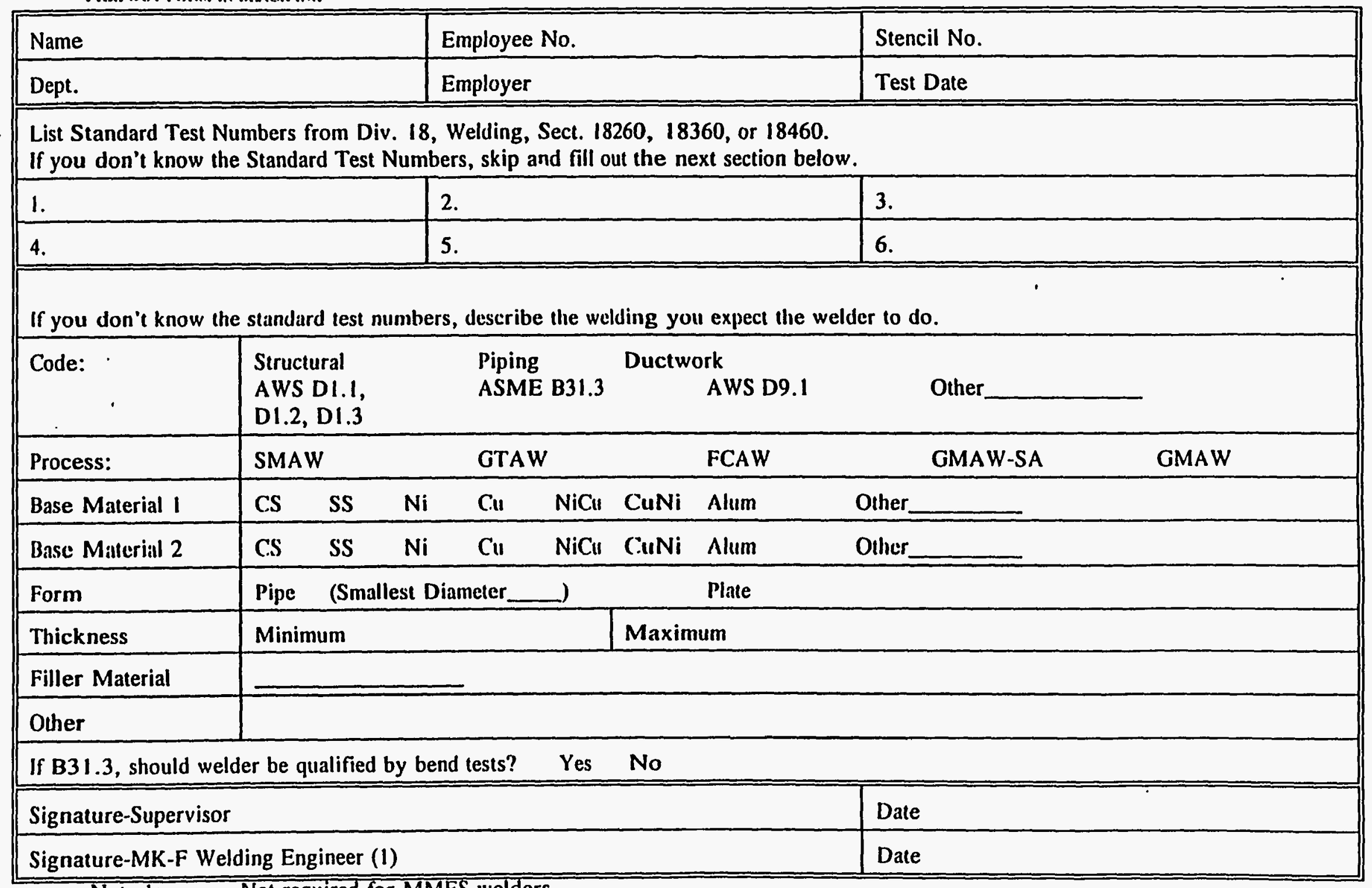

Note 1: Not required for MMES welders. 


\section{WELDER QUALIFICATION UPDATE REQUIREMENTS}

(MMES Oak Ridge Y-12 Plant Procedure Y10-65-EI-001, Appendix G)

All Martin Miarietta Energy Systems (MMIES), MK-Ferguson (MK-F), and Contractor welders whose qualifications are maintained by the $Y-12$ Weld Test Shop use this form to update.

Either of the following activities will update a welder's qualifications in the welding process used:

1. The welder using the process or procedure on a job observed by a welding inspector or supervisor. and that observation is documented.

2. The welder welding a sample coupon observed by a welding inspector or supervisor. and that observation is documented.

3. The welder welding an update test at the Y-12 Weld Test Shop.

The "Record of Welder or Welding Operator Process Usage" Form UCN-18983 is available from the Y-12 Weld Test Shop and is designed for documenting this activity. Fill out the form in black ink.

The following procedure is required:

1. The weider signs the form acknowledging use of the procedure.

2. The welding inspector, or the nelder's supervisor who observed the welding verifies this information for each procedure/process (GTAW, SMAW, GMAW, etc.) usage entry on the form.

3. The welder's supervisor signs at the bottom of the form verifying the accuracy and comp'.eteness of the form. The supervisor is responsible for the welder properly updating each qualifics:ion.

4. After a welding update test has been completed at the Weld Test Shop, the inspector admiristering the test signs as the person verifying use of the process and as the supervisor.

\section{MMES}

The MMES supervisors send the original form to the Weld Test Shop.

\section{$\underline{M K-F}$ and Contractors}

1. MK-F and Contractors keep the original form for their records and send a copy to the Wield Test Shop.

2. For MK-F and Contractor welders updating their qualifications at the Weld Test Shop, a copy of the form is retained by the Weld Test Shop and the original sent to the contractor.

The Weld Test Shop retains all records as necessary for audit purposes. 


\section{RECORD OF WELDER OR WELDING OPERATOR PROCESS USAGE}
$\square \mathbf{X}-10$
$\square \mathbf{K}-25$
口 Y-12

DHI.I. CHIT IVIIRM IN III.NC'K INK

\begin{tabular}{|c|c|c|c|c|c|}
\hline \multirow{2}{*}{\multicolumn{3}{|c|}{$\begin{array}{l}\text { WELDER'S NAME } \\
\text { DEPARTMENT }\end{array}$}} & \multicolumn{2}{|c|}{ EMPLOYEE NUMBER } & STENCIL NUMBER \\
\hline & & & \multicolumn{3}{|l|}{ EMPLOYER } \\
\hline $\begin{array}{l}\text { PROCEDURE/PROCESS } \\
\text { (GMAW,SMAW,GTAW,etc.) }\end{array}$ & $\begin{array}{l}\text { LAST USED } \\
\text { PROCESS } \\
\end{array}$ & $\begin{array}{l}\text { REOUALIFY } \\
\text { IBY }\end{array}$ & $\begin{array}{l}\text { DATE USED } \\
\text { PROCESS } \\
\end{array}$ & WELDER SIGNATURE & $\begin{array}{l}\text { INSPECTOR/SUPERVISOR } \\
\text { SIGNATURE }\end{array}$ \\
\hline & & & & & \\
\hline & & & & & \\
\hline & & & & & \\
\hline 1 & & . & & & \\
\hline & & & & & \\
\hline & & & & & \\
\hline & & & & & \\
\hline & & & & & \\
\hline & & & & - & \\
\hline & & & & & \\
\hline & & & & & \\
\hline SICINAIIIIRI:-SUIPI:IVISOIR & & & & 1)A11: & \\
\hline
\end{tabular}

RETURN THIS FORM TO T. S. LEACH, BLDG. 9709, MS-8092

THE SUPERVISOR IS RESPONSIBLE FOR THE WELDER PROPERLY UPDATING EACH QUALIFICATION. 


\section{ATTACHMENT C}

\section{FORM FOR CONTRACTOR ACCEPTANICE OF WPS}

Original on File at the Y.12 Weld Test Shop

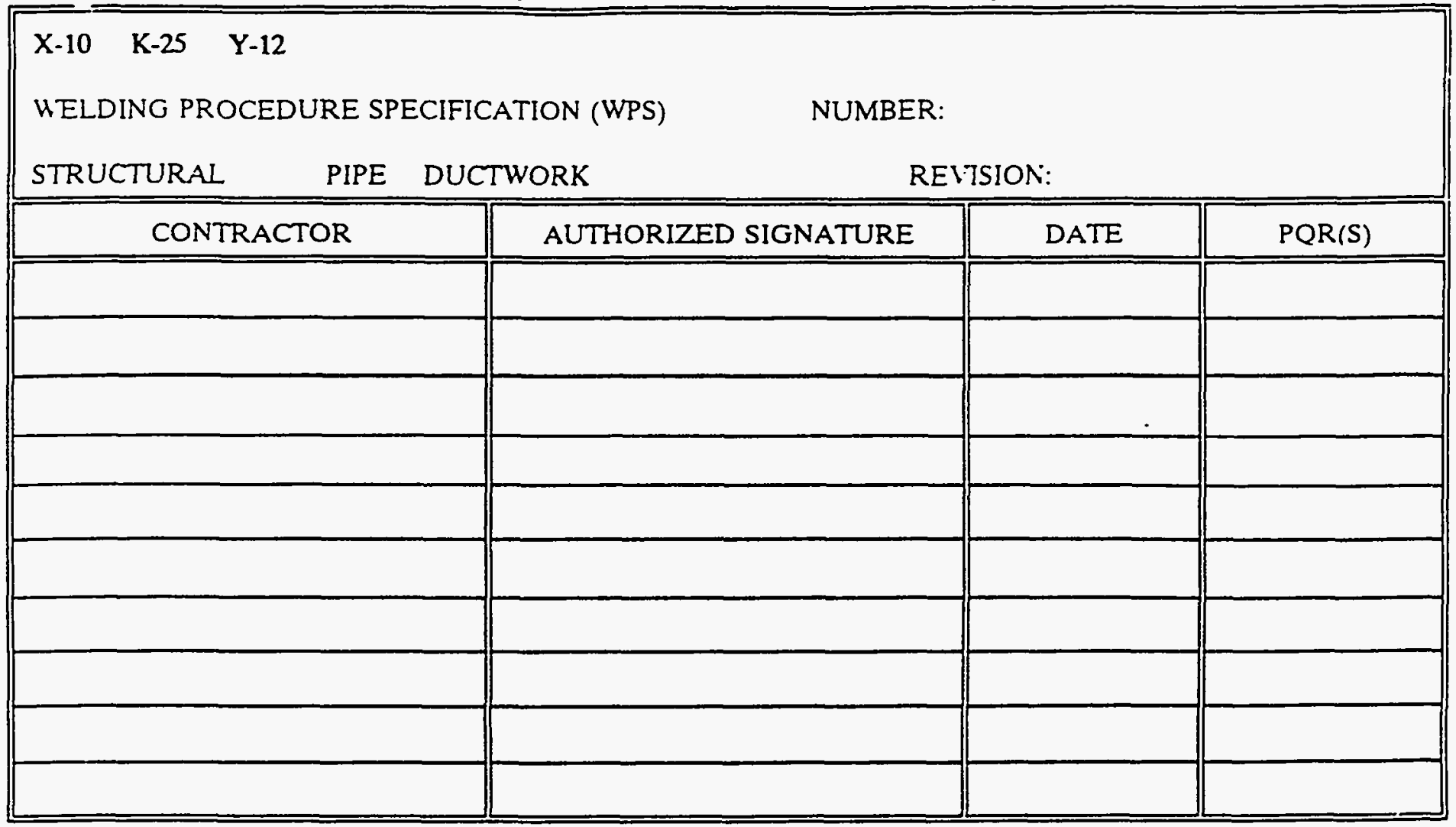

NOTE 1: $\quad$ For shared procedures as allowed by ASME B31.3, para. 328.2.2: procedures prequalified per AWS D1.1 or procedures qualified by the Facilities Manager per AWS D9.1. the PQRs are those listed on the WPS. T contractors signature asserts that he has reviewed and approves the WPS. the PQRs listed on the WPS. and the specifications referenced on the WPS. For ASME B31.3 shared procedures, the contractor must iden at all times one weider whose qualification was tested by bend tests. 
Attachment D

WELDING MACHINE REQUIREMENTS FOR FIELD WELDING

\section{$1.0 \underline{\text { SCOPE }}$}

These welding equipment requirements apply to construction, fabrication, or installation of metaljic systems such as piping, duct work, and structures in locations where the system is in direct contact with the ground (earth) or with low-resistance materials ahich are in contact with the ground.

\subsection{GENERAL REOUIREMENTS}

The purpose of this procedure is to prevent stray welding currents from passing through the earth and contributing to accelerated corrosion of components in contact with the earth. These requirements are in addition to requirements imposed by the Welding Procedure Specification.

\subsection{EOUIPMENT REOUIREMENTS}

3.1 Use welding machines with no less than one megohm electrical resistance between the welding machine output and the machine enclosure.

3.2 Use welding cables with a voltage rating of at least 600 volts, and electrical resistance to ground of the insulation (welding cable and cable connectors) of no less than one megohm.

3.3 Provide footswitches, when used, which cut off voltage to the electrode holder when released.

3.4 For testing equipment, use a motor driven megger with output voltage of at least 500 volts d.c.

\subsection{OPERATING PRACTICE}

4.1 Locate the welding machine as near the point of welding as possible, and support both cables (positive and negative) off the ground by methods which will provide electrical isolation from the ground during machine operation. Make both cables as short as practical.

4.2 Firmly clamp the grounding cable for good electrical contact at a location which will provide a low resistance path to the weld and not permit stray currents through the earth. Atrach the ground as near the weld as possible preferably on the material being welded (within 10 feet when possible).

4.3 Turn the welding machine off during extended periods of non-use such as lunch breaks, end-of-shift, or other welding delays.

4.4 The Facilities Manager inspector approves the initial setup at a job site and any significant changes in welding equipment artangements when the work is on material in direct physical contact with the earth.

4.5 Do not allow the welding torch and "hot" connectors to contact wet earth while the welding voltage is on. 


\subsection{EQUIPMENT TESTING}

5.1 The equipment owner/operator is responsible for assuring that the welding machine and welding cables meet the requirements of Section 3.0 prior to their installation at the job site.

5.2 Prior to use, have a qualified person test the welding equipment and/or allow the inspector to approve the equipment arrangement. No initial testing is required if sufficient information is provided as to the adequacy of the equipment. If the inspector questions any equipment. have the insulation tested in accordance with 5.3 or 5.4 by a qualified person.

5.3 Check the welding machine insulation resistance between the output terminals and the machine enclosure with the megger (Section 3.1 and 3.4) at 500 v.d.c. applied for a minimum of 15 seconds. CAUTION: If the inverse peak (I.P.V) rating of the rectifier is less than 500 volts, either short out the rectifier or use lower megger voltage.

5.4 Check the welding cable insulation integrity between the cable conductor and ground, with the cable arranged as for welding, with the megger at 500 v.d.c. applied for a minimum of 15 seconds for compliance with Section 3.2. If the initial test is made on a dry ground surface, repeat this test at the first opportunity following a rain while the cable and ground surfaces are wet. Follow this requirement for subsequent retests.

5.5 Install a $0-150$ volt d.c. voltmeter on the welding machine and connect to indicate welding machine output voltage. Check this meter daily to confirm proper operation of foot pedal control. If the output voltage does not return to zero when the foot pedal is released, perform maintenance or have the pedal replaced.

5.6 Repeat the resistance test of 5.3 and 5.4 at the request of the Facilities Manager inspector at intervals depending upon weather, site conditions, equipment handling care, etc. When machines or cables are being used in a wet or muddy environment, repeat the test at least once each month.

5.7 Document the equipment checks of 5.3 and 5.4. Attach a check-off card (see Fig. 1 for an example) to each welding machine.

5.8 When a foot switch is not required for welding control, use a non-conductive support approved by the Facilities Manager inspector for holding the welding electrode and clamp when not in use. Include this support in the test of 5.4 with the electrode connected to the cable and resting on the support. 


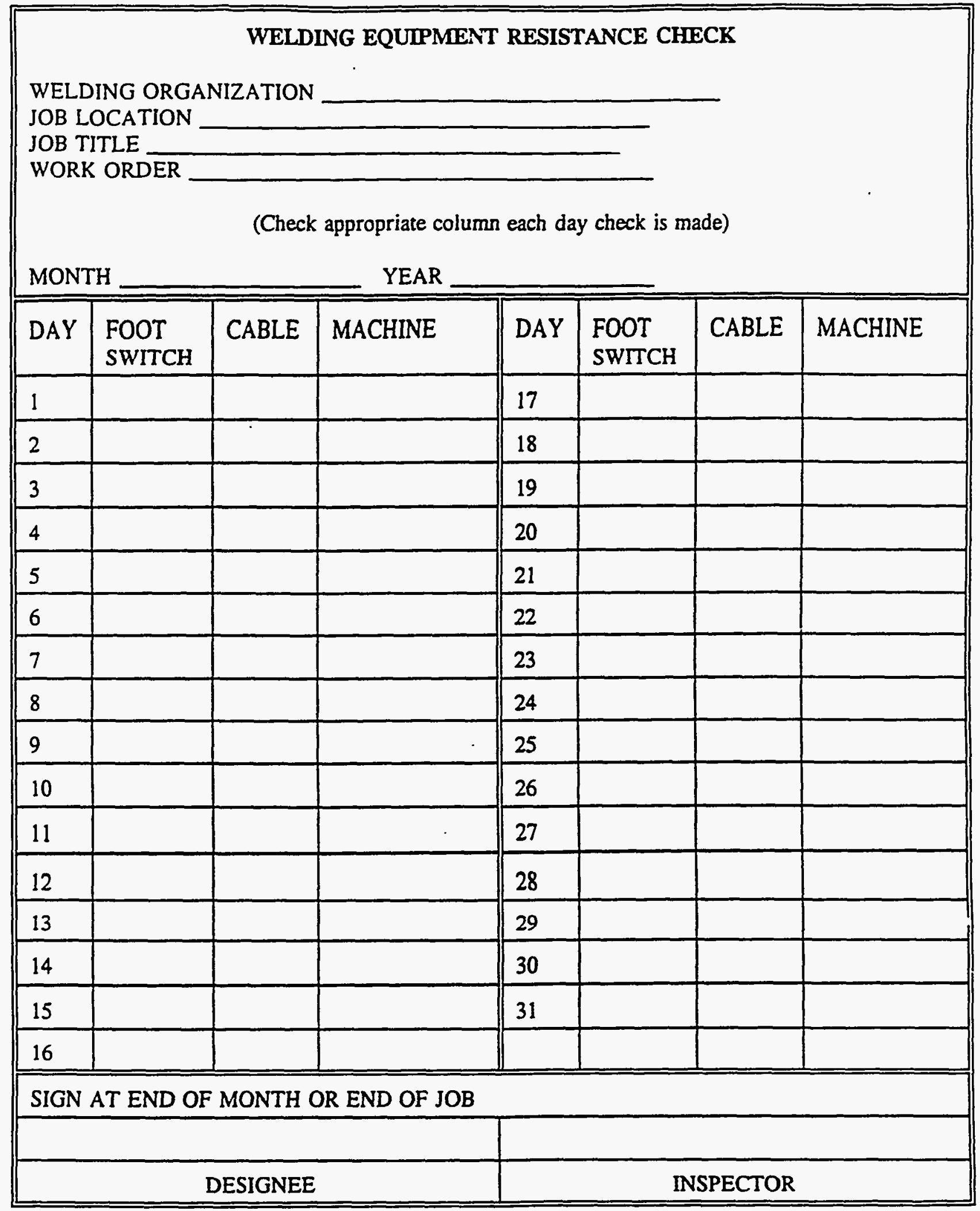

Figure 1 - Test Check Card 
MARTIN MARIETTA ENERGY SYSTEMS, INC.

OAK RIDGE, TN - PADUCAH, KY

ENGINEERING TRANSMITTAL

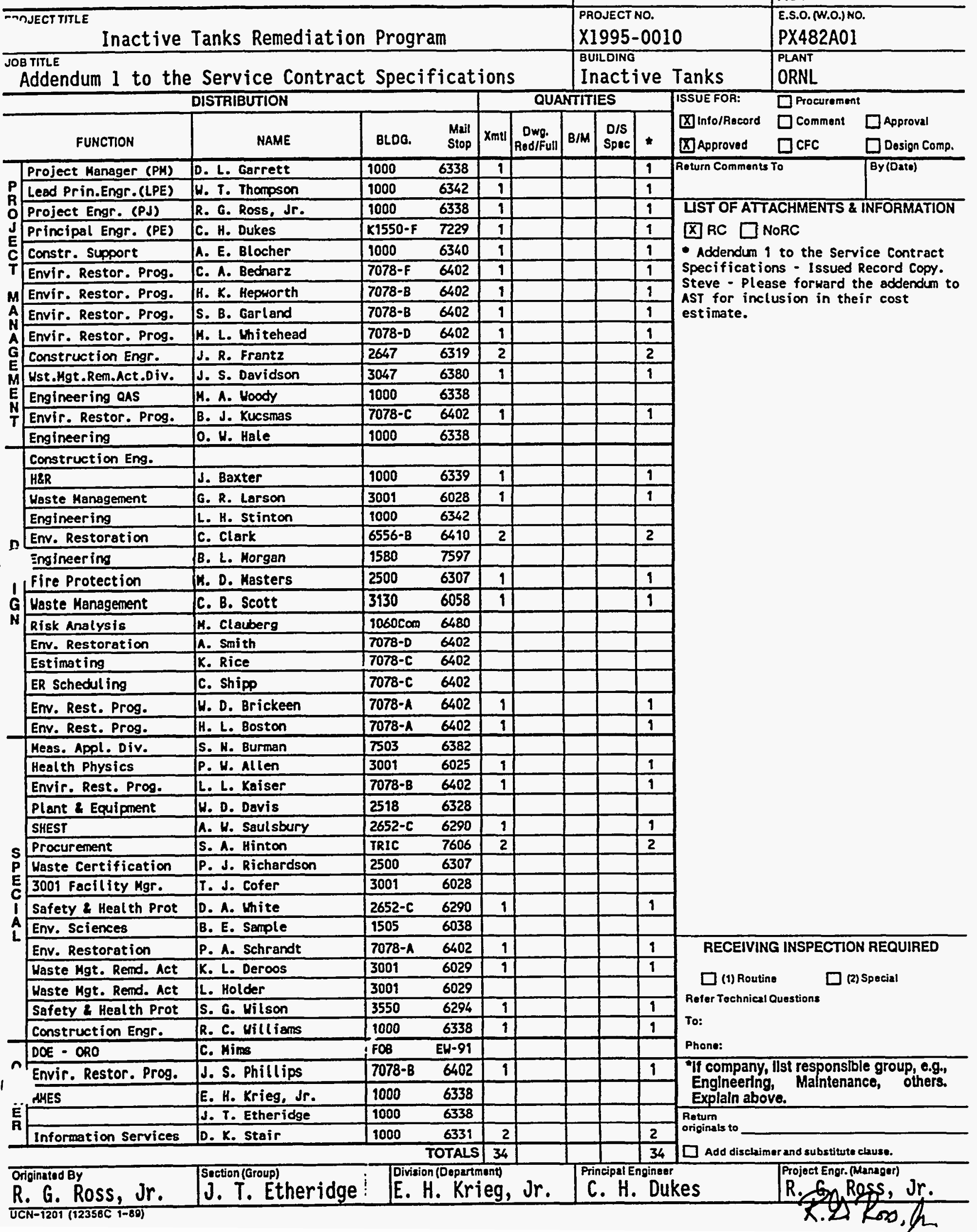


Addendum to Service Contract Specifications for Inactive Tanks 3001-B, 3004-B, 3013 and T-30.

1. Section 01010-5 1.09A. Change sequencing to:
1. 3004-B,
2. $\mathrm{T}-30$,
3. 3013 ,
4. 3001-B.

2. General: Include cost option of cutting tank T-30 into pieces, to allow for disposal in B-25 boxes ( $\left.4^{\prime} \times 4^{\prime} \times 6^{\prime}\right)$, in case the tank is not acceptable according to SEG's Waste Acceptance Criteria and must be disposed of on-site as rad waste.

3. Section 01010-6 3.02. Add "ORNL Respirator Training. Company provided, 1 hour", and "Confined Space Training: General confined space entry - for anyone entering the confined space, Company provided, 3.5 hours; Entrant/attendant - anyone entering the space and/or anyone serving as attendant, Company provided, 2.5 hours; Instrumentation for the person doing the atmospheric testing, Company provided, 8 hours; Supervisor for the supervisor of the confined space work, Company provided, 4 hours." Change "Respirator Coordinator training" to "Respirator Supervisor and Field Issuer training". Change "Lockout/Tagout Training" to Company provided, 4 hours.

4. Design Sketches: Add note to wrap tanks in plastic prior to transport to sea/land container.

5. SK3001B: Procedure 13: Backfill and rework concrete landing. Replace removed asphalt with concrete.

6. SK3004B: Procedure 7. Fill tank vault and valve pit area with grout.

7. SK3013: Change method of tank closure to the following:

Procedure 2. - Delete.

Procedure 3 - Change to: Excavate 3' to 4' at tank location.

Procedure 6. Cut and cap all lines 3 feet to 4 feet below grade excluding line \#3 shown in section A-A, Drawing D-1254. Removed piping sections will be disposed of in accordance with the Project Waste Management Plan.

Procedure 7. Fill tank with grout.

Procedure 9. Delete.

8. SKT30: Procedure \#7: Pour 6" reinforced (6" $\mathrm{x} 6 "-10$ wire mesh) 3000 psi concrete pad over pit. 
9. General: Delete requirement of Seller providing Radiological Control Technician (RCT). RCT will be provided by MMES.

10. General: Add "Seller shall assume that pipelines have liquids in them. Pipelines shall be "hot" tapped prior to cutting. Seller shall provide containers (or use Company provided 55 gallon drums if physical geometries permit) to collect any liquids in the pipelines Containers of liquid wastes will be stored in Waste Staging Area until characterization can be performed by the Company."

11. Section 01150-2 3.02. MMES will supply the Waste Certifier. AST will act as the waste generator. The generator's specific responsibilities are:

-Properly containerize, package and segregate all wastes generated as part of this project.

-Completes and signs box S1 of UCN Form 2109, Waste Item Description, and completes all parts of the form for which he has obtained information.

-If hazardous waste is generated, completes UCN Form 2109.

-Minimizes solid low-level radioactive waste (SLLW) production.

-Attends and successfully completes current ORNL SLLW generator training.

-Interfaces with the Waste Certifier to ensure that any issues in SLLW characterization are promptly brought to the attention of the responsible individuals and that nay new certification requirements or procedures are promptly instituted.

-Provides as much information as possible for certification of SLLW and documents the data on UCN Form 2109.

-Assists the WC with the preparation of the Waste Pickup Request form and Container Packing List.

12. Section 01150-4 2.01D-2. Change to read "Place removed cloth coveralls in Company supplied bags and deliver these bags to the Decontamination Laundry."

13. Section 01150-7 3.02C-5. Change to read: "Personnel shall wear field clothes (khakis) and coveralls (PPE).

14. Section 01150-8 3.02D-1a. Change to read: "Wear cotton glove liners under PPE working gloves.

15. Section 01150-9 3.04. Change to read "... the Company shall arrange for a bioassay, ..." 
16. Section 01160-3 1.01D-8. Change to read "A line or rope secured at one end to the worker's body harness, with the other end......"

17. Section 01180-2 2.01C. Change to read " The Subcontractor will be responsible for optical corrections for appropriate respirators.

18. Section 01180-3 3.03A-1. Change to read "The required number of respirators and cartridges will be requested by the Seller's Respirator Supervisor and Field Issuer at least 10 calendar days in advanze of the needed date. The Construction Engineer will coordinate the initial contact between the Seller and the MMES Respirator Issuer contact. The RCT will determine if single-use of respirators is required. The determination will be based upon the whether the respirators were used in a contamination area. If they were used in a contamination area, single-use of respirators will be followed. From the MMES Respirator Coordinator point of view, the respirators are issued for one shift only. If acceptable to the RCT (no contamination present), the respirators can be used repeatedly during one shift.

19. Section 01550-1 1.02D. Add: The Company will provide the sea/land containers for disposal of tanks.

20. Section 15146-1 1.03B. Change to read "ANSI b16.11, Factory-Made Wrought Socket Welding Fittings (1986).

21. Section 15146-2 2.01C. Change to read "...WP-W-304L, socketweld ends, ANSI B16.11."

22. Section 02200-2 3.02C-1. Change to read "... and compact using hand-operated power tampers."

23. SECTION 18100, Addendum 1

\section{GENERAL WELDING REQUIREMENTS}

Replace para. 3.04 with the following:

\subsection{EXAMINATION OF PIPING WELDS}

A. Required Examinations

1. Perform a final visual examination of all welds in accordance with ASME B31.3, para. 341.4.2.

2. Liquid-penetrant examine all pressure boundary welds and attachment welds to the pressure boundary after completion of the last layer of weld in accordance with ASME B31.3, para. 344.4. 
3. Examine fully by radiography all circumferential butt and miter groove welds in accordance with ASME B31.3, para. 344.5. Include at least $11 / 2$ in. of the longitudinal welds which intersect the circumferential or miter groove welds in those radiographed.

a. When approved by the engineer, in-process examination as described below may be substituted for all or part of the radiographic examination on a weld-for-weld basis:

\section{In-process Examination Requirements}

a. When approved by the Engineer perform the following visual examinations as a substitute for the required radiography:

1) joint preparation and cleanliness;

2) preheating;

3) fit-up, joint clearance, and internal alignment prior to joining;

4) variables specified by the joining procedure, including filler material, position, electrode, etc.;

5) condition of the root pass after cleaning--external and, where accessible internal--aided by liquid penetrant or magnetic particle examination when specified in the engineering design (As is the case for 15128);

6) slag removal and weld condition of at least each layer of weld metal. If the examiner is watching more than one welder there must be in place a control system which allows the examiner to establish a hold point so that the welder notifies the examiner after each layer of weld before progressing to the next layer;

7) a final weld examination for at least the attributes and to the acceptance criteria specified in ASME B31.3.

b. Records of individual weld examinations are required for in-process examinations.

\section{B. Acceptance}

1. The acceptance criteria of ASME B31.3, para. 341.3.2, and Table 341.3.2A for normal fluid service apply for visual and radiographic examination. Incomplete penetration identified by radiography is unacceptable. 
2. The acceptance criteria for liquid-penetrant examination follows:

a. Relevant indications are those with major dimensions greater than $1 / 16$ in.

b. The following relevant indications are unacceptable:

1) cracks and linear indications;

2) rounded indications with dimensions greater than $3 / 16$ in.;

3) four or more rounded indications in a line separated by 1/16 in. or less edge to edge; and

4) ten or more rounded indications in any 6 in. $^{2}$ of surface with the major dimension of this area not to exceed 6 in. with the area taken in the most unfavorable location relative to the indications being evaluated.

APPROVED BY: D. J. Etzler__ DATE: May 26, 1995

24. General: Contractor will be responsible for returning any areas damaged by heavy equipment back to its original condition. 


\section{DISTRIBUTION}

1. P. Allen

2. H. L. Boston

3. W. D. Brickeen

4. C. Callis (CDM Federal Programs Corporation)

5. C. C. Clark

6. S. B. Garland

7. D. L. Garrett

8. L. Hawke

9. R. G. Ross

10. A. W. Saulsbury

11. A. J. Kuhaida

12. P. T. Owen (2 copies)

13. P. A. Schrandt

14. M. L. Whitehead

15. P. S. Wood

16. ORNL Patent Section

17. Central Research Library

18. ER Document Management Center - RC ( 3 copies)

19. ORNL ER Document Management Center (3 copies)

20. ORNL Laboratory Records

21. Office of Assistant Manager for Energy Research and Development, DOE Oak Ridge Operations Office, P.O. Box 2001, Oak Ridge, Tennessee 37831-8600

22. Office of Scientific and Technical Information, P.O. Box 62, Oak Ridge, Tennessee 37831 . 